\title{
Is the isotopic composition of event based precipitation driven by moisture source or synoptic scale weather in the Sydney Basin, Australia?
}

\author{
Jagoda Crawford*, Catherine E. Hughes, Stephen D. Parkes \\ Australian Nuclear Science and Technology Organisation, Locked Bag 2001, Kirrawee DC, NSW 2232, Australia
}

\section{A R T I C L E I N F O}

\section{Article history:}

Received 16 May 2013

Received in revised form 2 October 2013

Accepted 18 October 2013

Available online 28 October 2013

This manuscript was handled by

Konstantine P. Georgakakos, Editor-in-Chief, with the assistance of Ana P. Barros,

Associate Editor

\section{Keywords:}

Stable isotopes

Precipitation

Back trajectories

East Coast Lows

Sydney Basin

\begin{abstract}
S U M M A R Y
Analysis of the isotopic composition of five years of event based precipitation samples collected in the Blue Mountains near Sydney Australia is presented. The relationship between the stable isotopic $\left({ }^{18} \mathrm{O}\right.$, D-excess) composition of precipitation with moisture source regions and prevailing synoptic scale weather systems was investigated. Back trajectory analysis showed that when the majority of moisture was sourced over land the $\delta^{18} \mathrm{O}$ was significantly more enriched $(-3.5 \%$ ) compared to moisture sourced from the ocean $\left(-7.1 \%\right.$ ). However, there was no statistically significant difference between the $\delta^{18} \mathrm{O}$ arithmetic means of different oceanic source regions. The analysis indicated that the large scale rainout during transport of moisture to the measurement site was a more important factor influencing the $\delta^{18} \mathrm{O}$ variability. A synoptic weather classification scheme was used to analyse the relationship with prevailing synoptic meteorology, which showed that the arithmetic mean of $\delta^{18} \mathrm{O}$ in precipitation for the East Coast Low (ECL) systems was significantly more depleted than other systems and exhibited much larger variability. There was no statistically significant difference in the $\delta^{18} \mathrm{O}$ arithmetic means of the other systems. The $\delta^{18} \mathrm{O}$ of the ECLs was shown to be related to the distance from low pressure system centre to the site and the large scale rainout along the back trajectory. Considering the large amount of precipitation that can result from ECLs, they may contribute significantly to signals observed over longer period collections such as the GNIP records. Winter and summer more depleted samples were from synoptic weather systems from which more precipitation had occurred both at the site and prior to the site. The enriched events could be associated with short duration low intensity precipitation events.
\end{abstract}

Crown Copyright (c) 2013 Published by Elsevier B.V. All rights reserved.

\section{Introduction}

The stable isotopic $\left({ }^{2} \mathrm{H}\right.$ and $\left.{ }^{18} \mathrm{O}\right)$ composition of precipitation has been used in investigations of groundwater and surface water mixing, infiltration, plant water use, land surface processes, and atmospheric processes over a variety of timescales (e.g. Awad, 1996; Clark and Fritz, 1997; Gat, 2000; Gat and Airey, 2006; Yoshimura et al., 2010). For monthly to inter-annual timescales, relationships between the stable isotopes of precipitation and temperature, elevation, distance from the coast, latitude and rainfall amount have been reported (Dansgaard, 1964). These relationships have been studied extensively using the Global Network of Isotopes in Precipitation (GNIP) data (e.g. Dansgaard, 1964; Araguas-Araguas et al., 2000), and have provided the basis for empirical models used to interpret paleoclimate records (Rozanski et al., 1993; McDermott, 2004; Field, 2010; Vachon et al., 2010; Treble et al., 2013). Whilst the GNIP network has provided major

\footnotetext{
* Corresponding author. Tel.: +61 29717 3885; fax: +61 297179260.

E-mail address: Jagoda.Crawford@ansto.gov.au (J. Crawford).
}

insights into the hydrological cycle, the samples are collected on a monthly basis and are not suitable to study the relationships between the isotopes in precipitation and synoptic scale weather systems. Datasets with higher frequency sampling may provide a useful basis for interpreting signals in paleoclimate records associated with climatic shifts in the synoptic meteorology.

For a precipitation event, the isotopic composition is determined by the source composition, atmospheric conditions at the site of evaporation, precipitation processes, and mixing during transport to the site of sampling. This leads to a large amount of variability between individual precipitation events at a given location (Dansgaard, 1964; Noone and Simmonds, 2002a; Sjostrom and Welker, 2009; Vachon et al., 2010). It has been reported that the isotopic values of precipitation at a site can vary due to changes in synoptic weather patterns (Treble et al., 2005; Barras and Simmonds, 2008; Scholl et al., 2009; Baldini et al., 2010; Lykoudis et al., 2010). In particular, for a site in Tasmania, well developed low pressure systems have been found to be associated with lower $\delta^{18} \mathrm{O}$ values (Treble et al., 2005; Barras and Simmonds, 2008). Alternatively, higher frequency data has been used to study the 
relationship between precipitation isotopes and moisture sources using back trajectory analysis (e.g. Friedman et al., 2002; Burnett et al., 2004; Sjostrom and Welker, 2009). Therefore, expanding the temporal resolution beyond the monthly GNIP dataset to include daily or event based sampling regimes may provide further insights into the atmospheric processes important for individual storm events.

A related quantity, deuterium excess (D-excess $=\delta^{2} \mathrm{H}-8 \delta^{18} \mathrm{O}$; Dansgaard, 1964) is influenced by the relative humidity (negative correlation) and sea surface temperature (SST; positive correlation) at the moisture source (Dansgaard, 1964; Merlivat and Jouzel, 1979; Uemura et al., 2008). Using this relationship, D-excess has been used in many studies to determine the temporal changes in moisture supply for a given location (e.g. Vimeux et al., 2001). Dexcess is also commonly used as an indicator of the evaporation of raindrops under the cloud base under warm dry conditions (which reduces the $\mathrm{D}$-excess of the rainfall) and moisture recycling by evaporation from the land surface (which increases the D-excess of the rainfall), (Jacob and Sonntag, 1991; Froehlich et al., 2008; Peng et al., 2010).

Studies of higher frequency $\delta^{18} \mathrm{O}$ in precipitation in the Australian region include sites in Tasmania (Treble et al., 2005; Barras and Simmonds, 2008), Melbourne (Barras and Simmonds, 2009), Adelaide (Guan et al., 2009, 2013) and four sites in the Sydney region (Hughes and Crawford, 2013).

The objective of this study was to investigate the extent to which spatial locations of moisture sources and synoptic weather patterns influence the isotopic variability in precipitation at $\mathrm{Mt}$ Werong, in the Blue Mountains west of Sydney. The moisture source isotopic composition varies depending on the proportion of moisture sourced from the ocean surface and evapotranspiration from the land surface. Evapotranspiration returns moisture to the atmosphere with relatively little fractionation compared to the source water which therefore tends to be enriched relative to vapour derived from the ocean (Zimmermann et al., 1967; White and Gedzelman, 1984; Barnes and Allison, 1988; Wang and Yakir, 2000; Welp et al., 2008; Jasechko et al., 2013). For moisture derived from the ocean the isotopic composition of the water vapour varies with the SST and relative humidity (Majoube, 1971; Dansgaard, 1964; Clark and Fritz, 1997; Uemura et al., 2008; Lachniet, 2009). Moisture derived from the ocean can therefore vary with oceanic source region. Here we investigate relationships between the geographic location of the moisture source, the atmospheric conditions at the moisture source and the isotopic composition of the precipitation sampled at the Mt Werong site.

Classification by weather systems was used to investigate the extent to which atmospheric processes (both at the source, incloud processes and below cloud processes) have an impact on the isotopic composition of precipitation, as similar atmospheric conditions are grouped together. Studies have found more isotopically depleted precipitation from low pressure systems and more enriched precipitation associated with trade winds and high pressure systems (e.g. Scholl et al., 2009; Baldini et al., 2010; Windhorst et al., 2012). The amount effect associated with convective systems can be attributed to two processes (Risi et al., 2008); (a) the re-evaporation of the falling rain and the diffusive exchange with the surrounding vapour and (b) the re-cycling of sub-cloud layer vapour feeding the convective system by convective fluxes. Isotopically more enriched precipitation may occur from high pressure systems due to land surface moisture re-cycling and lower altitudes reached by the clouds (Scholl et al., 2009).

Since 2005 precipitation samples have been collected for isotopic analysis at four sites in the Sydney region, including Mt Werong (Hughes and Crawford, 2013). At the Mt Werong site an event based sampling regime was implemented between 2005 and 2009 and these samples are examined in the current work.
The results presented in this paper give further insights into the controls on $\delta^{18} \mathrm{O}$ and $\delta^{2} \mathrm{H}$ of precipitation in the Sydney region.

A description of the study site and data used in the analysis are presented in Section 2. The seasonal distribution of precipitation and isotopic composition are presented in Section 3.1. Air mass back trajectory classifications and synoptic weather pattern classification are presented in Sections 3.2 and 3.3, respectively, and finally the synoptic weather patterns for the winter and summer enriched and depleted samples are presented in Section 3.4.

\section{Study site and data sources}

\subsection{Study site}

Mt Werong is located at the SW extent of the Blue Mountains of New South Wales, $97 \mathrm{~km}$ from the coast $\left(34.07893^{\circ} \mathrm{S}, 149.91330^{\circ} \mathrm{E}\right.$, at an elevation of $1178 \mathrm{~m}$ above sea level, see Fig. 1). Vegetation in the vicinity of the sampling site is dry sclerophyll eucalypt forest and shrub land giving way to taller cool montane wet forest towards the north and east. Seven km to the NW pine plantations grade into cleared agricultural and grazing land. Mt Werong is located $40 \mathrm{~km}$ west of Lake Burragorang (surface area $75 \mathrm{~km}^{2}$ ), Sydney's main drinking water supply. It is also in the vicinity of two sites where isotopic studies of speleothems and groundwater have been undertaken: Jenolan Caves $30 \mathrm{~km}$ to the north (e.g. Pogson et al., 2011) and Wombeyan Caves, $26 \mathrm{~km}$ to the south. The site for the precipitation collection was located on a ridge within a partially cleared rural property surrounded by the Blue Mountains National Park.

The climate for the Sydney region is characterised as warm temperate, fully humid with warm summers (Kottek et al., 2006). Meteorological data from the Gurnang State Forest (Oberon) station (BOM station $063033,34.01^{\circ} \mathrm{S}, 149.84^{\circ} \mathrm{E}$, elevation $1148 \mathrm{mAHD}$ ), located $10.3 \mathrm{~km}$ northwest of the Mt Werong site, has a mean annual temperature of $9.8^{\circ} \mathrm{C}$, mean annual precipitation of $984 \mathrm{~mm}$ and mean number of rain days of 101.2 (for 1933 to 2008).

\subsection{Precipitation sample collection}

Precipitation samples were collected in a sealed HDPE sampling bottle with a plastic funnel. The sampler was designed to prevent evaporation of the sample or exchange with the atmosphere in a similar fashion to that described by Gröning et al. (2012). Testing of the sampler and quality control has been described in Hughes and Crawford (2013).

$\delta^{2} \mathrm{H}$ and $\delta^{18} \mathrm{O}$ were determined for 289 samples (March 2005 to September 2009) with results expressed in per mille (\%o) using the conventional delta notation relative to VSMOW. Four different laboratories were used to conduct the analyses (the reported lab precision for $\delta^{2} \mathrm{H}$ and $\delta^{18} \mathrm{O}$ respectively is given in \%o following the lab name): University of Waterloo Environmental Isotope Laboratory $(0.8,0.2)$; INSTAAR Stable Isotope Laboratory $(0.6,0.08)$; University of California at Berkeley Centre for Stable Isotope Biogeochemistry $(1,0.1)$; and Alberta Research Council Isotope Hydrology and Geochemistry Laboratory $(1,0.2)$.

For the study period hourly precipitation measurements were available from the Sydney Catchment Authority (SCA Station 563050 Mount Werong (Venns Property), located $370 \mathrm{~m}$ SE of the sampler location) which were used in this study for determining the time of precipitation. This data was in good agreement with the daily precipitation amount collected at the site (with an $r^{2}$ value of 0.95 and ratio of manual to tipping bucket rain gauge of 1.08). During the precipitation sampling the end of a precipitation event, and thus the sample collection time, was determined by the local volun- 


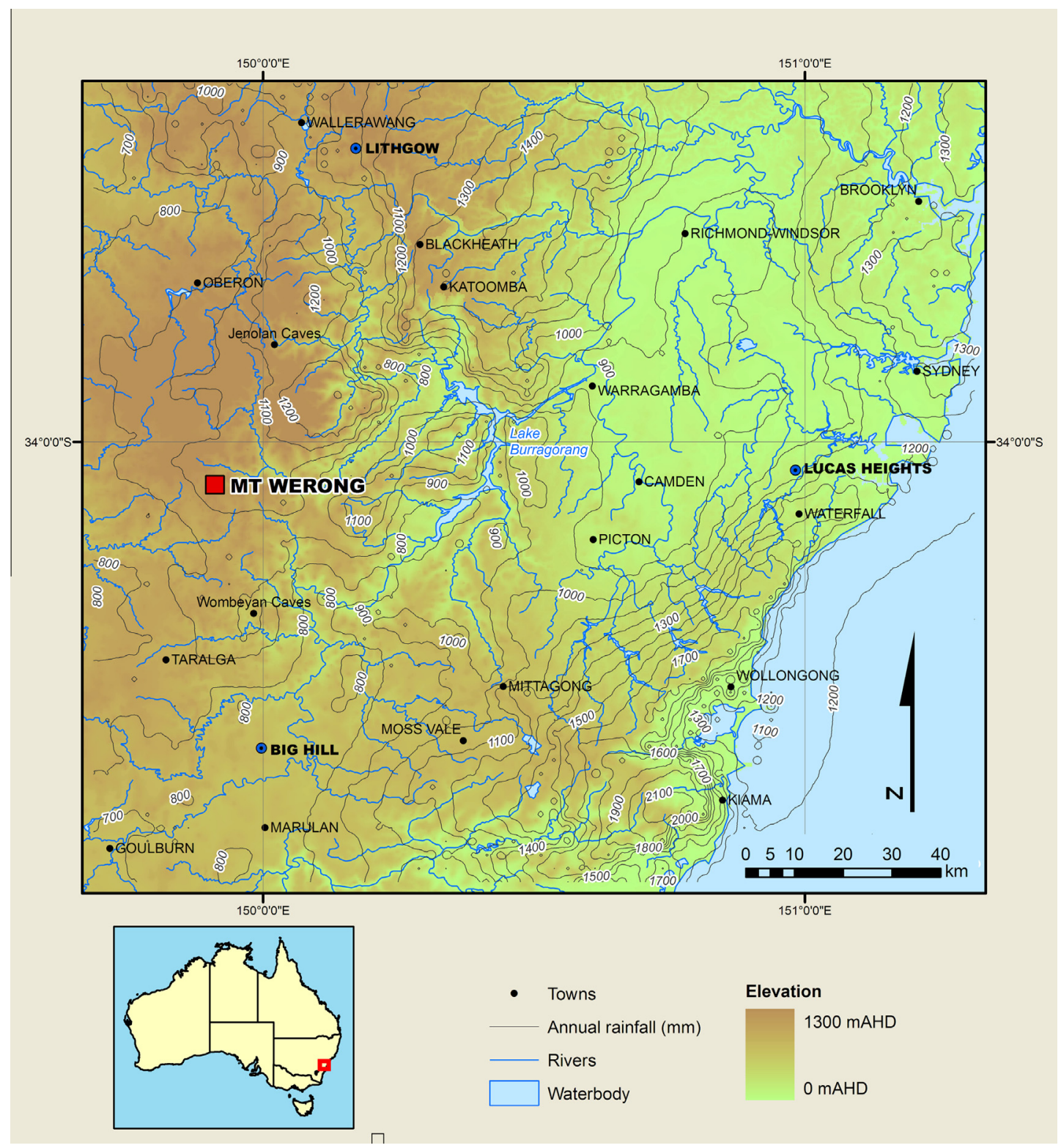

Fig. 1. Sydney region map showing study site, precipitation contours and topography.

teer. In this study, events were defined as precipitation occurrences separated by $6 \mathrm{~h}$ or more without precipitation (Dunkerley, 2008; Manfroi et al., 2004; Scholl et al., 2009), to ensure that precipitation for each event resulted from moisture sourced from the same locations and/or from the same synoptic weather system. Between March 2005 and September 2009, of the 289 samples collected 146 satisfied the criteria of a single event and only these are used in the analysis presented below. Both low and high intensity precipitation events were well represented in the reduced data set.

\subsection{Back trajectory and trajectory meteorological data}

Back trajectories and meteorological information along back trajectories can give an indication of the moisture sources as well as the large scale rainout from the air mass (e.g. Friedman et al., 2002; IAEA, 2005; Barras and Simmonds, 2008; Sodemann et al., 2008; Sjostrom and Welker, 2009; Vachon et al., 2010). Back trajectories in the current study were generated using the PC version of HYSPLIT v4.0 (HYbrid Single-Particle Lagrangian Integrated
Trajectory; Draxler and Rolph, 2003), using the GDAS $1^{\circ} \times 1^{\circ}$ meteorological dataset. In addition to using the location of the back trajectories, we also use the altitude of trajectories, relative humidity, planetary boundary layer height and precipitation, as calculated by the HYSPLIT model at each point along the back trajectory, to examine moisture sources and rainout.

To determine the source of moisture the method of Sodemann et al. (2008) was implemented. This involves generating a vertical profile of the relative humidity at the site from the GDAS data, then calculating the back trajectory starting at the lowest altitude where the relative humidity was $>80 \%$ (as used by Sodemann et al., 2008), resulting in most back trajectories being calculated at a starting height between $1500 \mathrm{~m}$ above mean sea level (msl) and $3000 \mathrm{~m}$ msl. Back trajectories for each sample were calculated only for those hours for which precipitation was recorded at the site, during the previous $60 \mathrm{~min}$.

Along the 10 day back trajectories (corresponding to a mean residence time of water in the atmosphere of about 10 days, Trenberth, 1998; Gat, 2000; Friedman et al., 2002), at locations where 
moisture was evaporated from the surface, precipitation weighted averages of surface relative humidity and temperature were calculated from the HYSPLIT estimated relative humidity and temperature at surface level. The locations of surface moisture sources were identified as points along the back trajectory where absolute humidity increased by more than $0.04 \mathrm{~g} \mathrm{~kg}^{-1} \mathrm{~h}^{-1}$ and when the air mass was within the planetary boundary layer (PBL), according to Sodemann et al. (2008). When the absolute humidity was below $0.05 \mathrm{~g} / \mathrm{kg}$ it was assumed that no previously sourced moisture contributed to the current precipitation event (Sodemann et al., 2008; Baldini et al., 2010). The air mass prior cumulative rainfall was also calculated as the sum of rainfall along the back trajectory prior to the site starting from the last point where moisture was sourced for the current event.

To determine the contribution of different moisture source regions, the Australian region was subdivided into six possible moisture source regions. For each back trajectory the fraction of moisture evaporated into the air mass from each moisture region $\left(f_{i, j}\right.$, i.e. the fraction of moisture from region $j$ for trajectory $\left.i\right)$ was estimated from the change in the absolute humidity when the back trajectory passed over the specified region (where $\sum_{j=1}^{6} f_{i, j}=1$ for all $i$ ). When groups of back trajectories were used in the analysis (i.e. in Sections 3.2 and 3.4), the contribution from each region was weighted by the recorded precipitation at the measurement site to obtain the precipitation weighted fraction from region $j$ $\left(M_{j}\right)$ :

$M_{j}=\frac{\sum_{i=1}^{n} p_{i} f_{i, j}}{\sum_{i=1}^{n} p_{i}}$

where $n$ is the number of back trajectories.

That is, for all the samples classified into a single group the percentage of moisture, for that group, sourced from region $j$ is estimated by $M_{j}^{*} 100$.

\subsection{Synoptic weather classification}

A synoptic weather classification system was used to investigate the relationship between the stable isotopes in the precipitation samples and common precipitation producing synoptic weather systems. The classification system outlined by Matthews and Geerts (1995; see also Speer and Geerts, 1994) for the Sydney region was implemented here and contains six main groups. Example Mean Sea Level Pressure (MSLP) maps corresponding to these classifications were presented in Matthews and Geerts (1995)
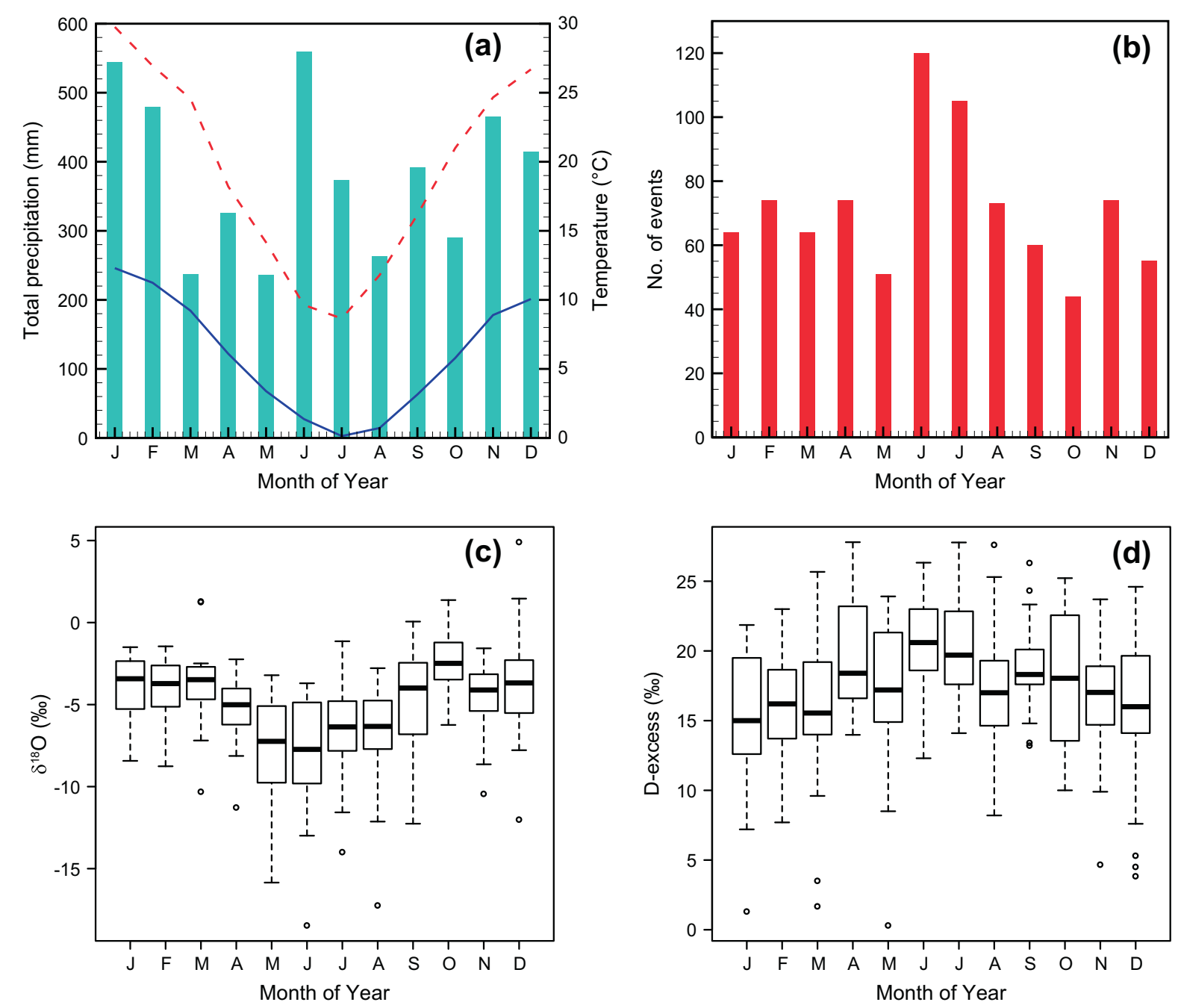

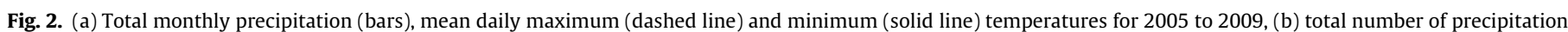

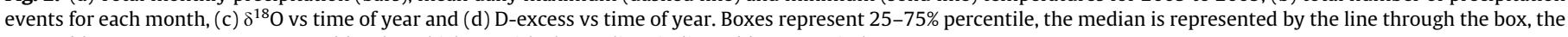
top and bottom $25 \%$ are represented by the whiskers with the outliers indicated by open circles. 
and were identified as follows (in this study, average MSLP maps for samples classified in each group are presented in Section 3.3):

- East Coast Lows - closed cyclonic low pressure systems off the east coast (ECL: Speer et al., 2009, referred to as offshore lows in Matthews and Geerts, 1995), occur more frequently in winter and their locations vary in latitude and longitude to the east and southeast of the site.

- Offshore high - where an offshore high pressure system is located to the east or southeast of the site, occurring both in winter and summer.

- Inland troughs - these occur throughout the year but more samples were collected under inland trough conditions in spring and summer. Their location varies over the eastern part of the continent. This group also contains non-cyclonic low pressure centres (i.e. over land).

- Pre-frontal trough - where troughs appear separate and ahead of a cold front.

- Pre-frontal - where precipitation resulted from the frontal trough, ahead of the local passage of the front.

- Post-frontal - where precipitation events occurred during and immediately after the passage of the front.

To identify the weather systems resulting in precipitation a combination of Mean Sea Level Pressure (MSLP) (BOM, 2012) and NCEP/NCAR reanalysis sea level pressure (Kalnay et al., 1996) were used. Further, for samples classified in each synoptic weather type, a composite MSLP was calculated using sea level pressure from the NCEP/NCAR Reanalysis (which is provided on $2.5^{\circ} \times 2.5^{\circ}$ grid cell size and the data are available at $6 \mathrm{~h}$ time intervals). The time interval in the reanalysis dataset which was closest to the time of precipitation was selected. The average sea level pressure was then calculated for each grid space within the domain of interest (latitude $10^{\circ} \mathrm{N}$ to $60^{\circ} \mathrm{S}$ and longitude $100^{\circ} \mathrm{E}$ to $180^{\circ} \mathrm{E}$ ) from the sea level pressure for all events within the classification.

No attempt was made to separate the weather systems, based on moisture sources, aside from the natural characteristic separation, e.g. the moisture source for the ECL systems was mostly from the east and south-east of the site, for post frontal systems from the west and south west. For inland troughs the moisture source was more variable.

\section{Results and discussion}

Hughes and Crawford (2013) presented $\delta^{18} \mathrm{O}$ and D-excess time series as well as relationships with local meteorological conditions

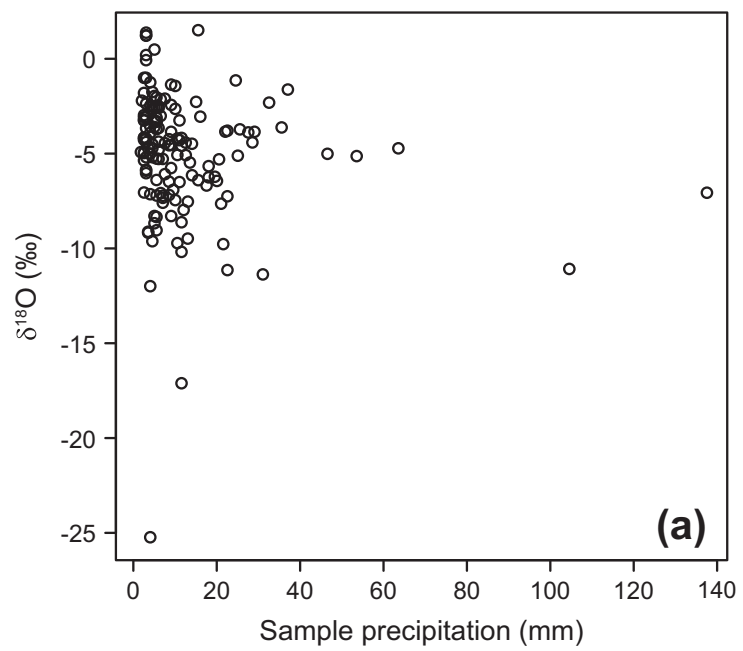

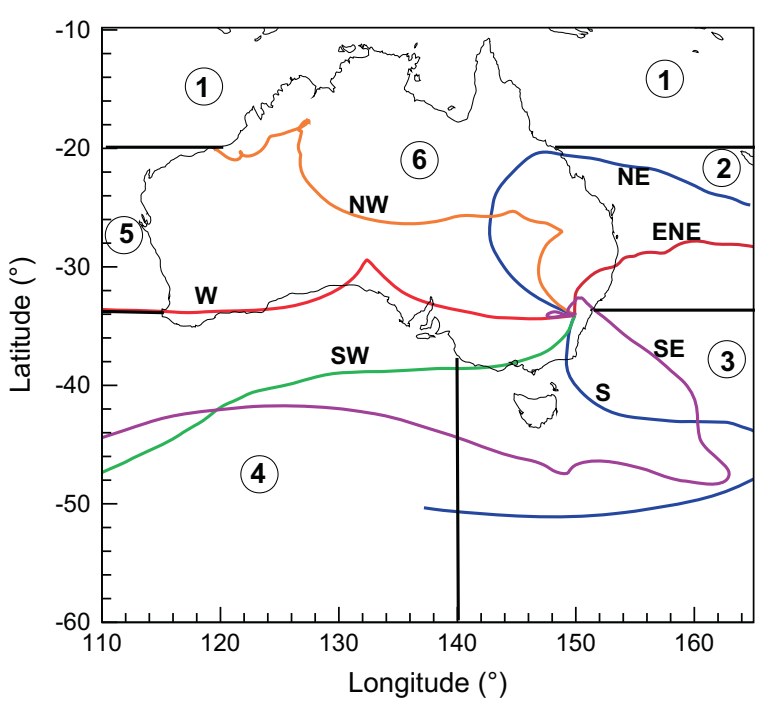

Fig. 4. Representative back trajectory for each of the 7 clusters northwest (NW), northeast (NE), east-northeast (ENE), southwest (SW), south (S), southwest (SW), and west (W). Moisture regions also presented in circles; (1) Ocean north of latitude $-20^{\circ}$, (2) Pacific Ocean between latitude $-20^{\circ}$ and $-34^{\circ}$ (i.e. north of the site), (3) Ocean below latitude $-34^{\circ}$ and longitude greater than $140^{\circ}$, (4) Ocean below latitude $-34^{\circ}$ and longitude less than $140^{\circ}$, (5) Indian Ocean between latitude $-20^{\circ}$ and $-34^{\circ}$, and (6) the Australian Continent

for four collection sites in the Sydney region. At three of these sites the precipitation was sampled on event basis and on a weekly basis at the fourth site. Here we present an analysis of event based samples from one site, Mt Werong.

\subsection{Seasonal cycle}

The monthly total precipitation amount and the number of events for the five years (January 2005 to December 2009, also including un-sampled short duration light precipitation events) are presented in Fig. 2. No obvious seasonality was seen in monthly precipitation amount at Mt Werong (Fig. 2a) from 2005 to 2009, however, more precipitation events occurred in June and July (Fig. 2b). The average annual precipitation for the five years was $916 \mathrm{~mm}$, which was 7\% less than the long term annual average for the region of $984 \mathrm{~mm}$ (for 1933-2008, BOM Site 063033). The seasonal variation in temperature (Fig. 2a) was high with cool winters and warm summers.

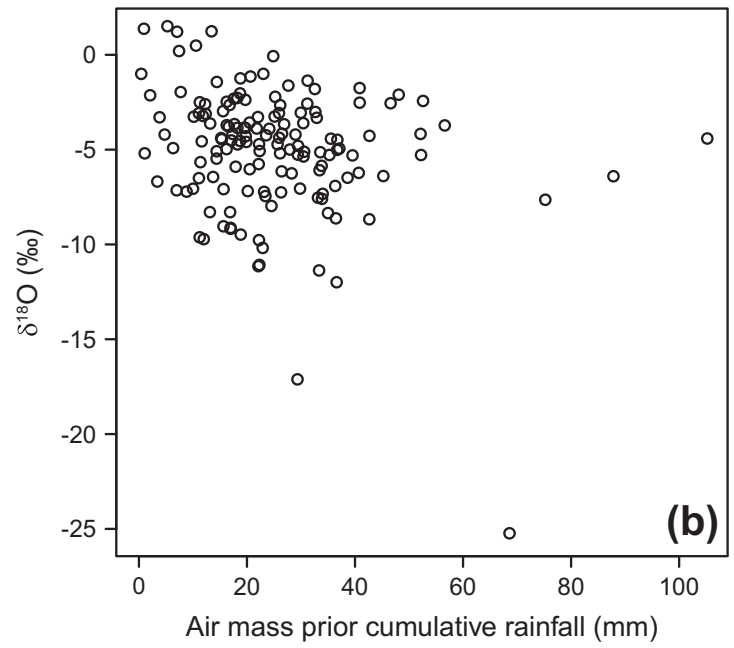

Fig. 3. Scatter plot of sample $\delta^{18} \mathrm{O}$ vs (a) sample precipitation at the site; and (b) air mass prior cumulative rainfall, for all single event samples. 
To avoid duplication, only $\delta^{18} \mathrm{O}$ and $\mathrm{D}$-excess values are presented in Fig. $2 \mathrm{c}$ and d, respectively. $\delta^{18} \mathrm{O}$ values for the winter precipitation were more variable than summer and the median values were more depleted than for summer (more depleted values in winter are consistent with e.g. Feng et al., 2009 in their analysis of the GNIP data). The D-excess was generally high compared to globally (Feng et al., 2009) but was closer to the D-excess of the other sites in the Sydney region, where the precipitation weighted average D-excess ranged from $15.45 \%$ or Big Hill to $18.33 \%$ for Mt Werong (further discussed in Hughes and Crawford, 2013). The seasonal cycle for the D-excess values showed higher values in winter than summer but had large variability within seasons.

For all the single events, the correlation between the $\delta^{18} \mathrm{O}$ of samples and the precipitation amount at the site was $(r=)-0.15$, which was significant at $93 \%$ confidence level ( $p=0.07$, Fig. 3a). This is consistent with other sites in the Sydney region (Hughes and Crawford, 2013), indicating that the amount effect is weak in this region. An improved correlation $(r=-0.25$ with $p$-value $=0.002$ ) was observed between $\delta^{18} \mathrm{O}$ and the air mass prior cumulative rainfall (Fig. 3b). The difference between these correlations indicates that local precipitation amount does not provide a good indicator of the air mass rainout and rather reflects the local state of the precipitation event. However, whilst improved, the correlation with the air mass prior cumulative rainfall is still small which indicates that other factors are more important in setting the $\delta^{18} \mathrm{O}$ composition of event based precipitation samples.

\subsection{Moisture source regions}

There is a small variation in $\delta^{18} \mathrm{O}$ of Australian marine surface waters $(\sim 0.1 \%$ over the oceans to the east and west of the continent and $\sim-0.1 \%$, in the Southern Ocean; Bigg and Rohling, 2000). However, the isotopic composition of the evaporating water vapour can be affected by the sea surface temperature (SST) and surface level relative humidity at the site of evaporation (Majoube, 1971; Dansgaard, 1964; Clark and Fritz, 1997; Uemura et al., 2008; Lachniet, 2009). For the Australian region, SST varies seasonally and decreases with latitude. The long term SSTs (1971-2000, available at http://www.esrl.noaa.gov/psd/data/gridded/data.noaa.oisst.v2.html; Reynolds et al., 2002) show a decrease from $25^{\circ} \mathrm{C}$ (at latitude $15^{\circ} \mathrm{S}$ ) to $7^{\circ} \mathrm{C}$ (at $50^{\circ} \mathrm{S}$ ) for winter and $28.5^{\circ} \mathrm{C}$ to $7.5^{\circ} \mathrm{C}$ for summer, at the same latitudes.

The long term ocean surface level average relative humidity (for January and July, 1968 to 1996, available at http://www.esrl.noaa.gov/psd/data/reanalysis/reanalysis.shtml; also supplied in Supplementary Fig. 1) shows little variation with season over the ocean to the north and south (with relative humidity of $80-85 \%$ to the north, and $85-90 \%$ in the south). Some variations between the seasons are seen over the oceans with latitudes closer to the measurement site; $75-80 \%$ in June and $80 \%$ in January. However, when individual samples are considered, variations from these average values would be experienced.

To investigate the impact from air mass trajectory prior to the site, and hence the moisture sources, each single event sample was classified, by visual inspection of HYSPLIT generated back trajectories, into one of seven clusters (Fig. 4, in which figure the six identified moisture regions are also presented). A small number of samples had air masses arriving from different directions, in which case the sample was classified into the cluster based on the air mass trajectory corresponding to the larger precipitation amount. The largest average precipitation (Table 1) was from air masses arriving from the east (i.e. trajectories labelled east-northeast and southeast with average sample precipitation of $18 \mathrm{~mm}$ and $15.55 \mathrm{~mm}$, respectively). Together they comprised $37 \%$ of the single event samples (Table 1). A large number of events were also associated with air masses arriving from the southwest (22\%), however the average sample precipitation from these air masses was $7.28 \mathrm{~mm}$, which may have been associated with lower air mass moisture content due to the cooler conditions.

\subsection{1. $\delta^{18} \mathrm{O}$ distribution with back trajectory clusters}

The distribution of $\delta^{18} \mathrm{O}$ within each cluster is presented in Fig. $5 \mathrm{a}$ together with the precipitation weighted average $\delta^{18} \mathrm{O}$ (blue crosses, the corresponding values are also included in Table 1). Higher precipitation weighted average $\delta^{18} \mathrm{O}$ values were recorded for moisture sourced from north of the site (i.e. clusters labelled northwest and northeast). Moisture in these clusters was sourced under high surface level temperatures (Table 1) which would result in more enriched water vapour (e.g. Friedman et al., 2002; Uemura et al., 2008). Precipitation when moisture was sourced from the west had the next most enriched precipitation weighted mean $\delta^{18} \mathrm{O}$, but the standard deviation was higher than for moisture sourced from the northeast. However, when a $t$-test was undertaken to evaluate the significance in the difference of the arithmetic means between the clusters, it was only the northwest cluster that had a significantly different arithmetic mean $\delta^{18} \mathrm{O}(p$ value $=0.01$ ) to the other clusters. The differences between the arithmetic means of the other clusters were not statistically significant. This may be an indication that condensation and mixing processes are the driving factors of the $\delta^{18} \mathrm{O}$ values and that conditions over the oceanic moisture sources are insufficiently different to cause large changes in the isotopic composition at the precipitation site. This is in contrast, for example, to Friedman et al. (2002) who found that precipitation at Cedar City (Utah) from air masses arriving from the Gulf of Mexico was the most enriched in $\delta^{2} \mathrm{H}$, which they concluded was due firstly to the isotopically enriched surface waters of the Gulf of Mexico and the warm surface water temperature, and secondly to reduced rainout from the air masses before the site.

\section{Table 1}

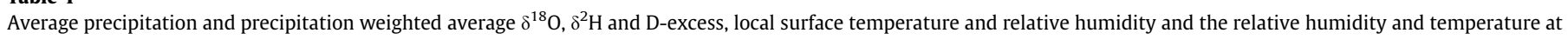
the surface level at the moisture source, for the 7 identified clusters. The standard deviation is also presented in brackets.

\begin{tabular}{|c|c|c|c|c|c|c|c|c|c|c|}
\hline \multirow[t]{2}{*}{ Cluster } & \multirow[t]{2}{*}{$N$} & \multirow[t]{2}{*}{$\begin{array}{l}\text { Arithmetic Av. Precip. } \\
(\mathrm{mm})\end{array}$} & \multirow[t]{2}{*}{$\delta^{18} \mathrm{O}(\% o)$} & \multirow[t]{2}{*}{$\delta^{2} \mathrm{H}(\%)$} & \multirow[t]{2}{*}{$\begin{array}{l}\text { D-excess } \\
(\%)\end{array}$} & \multirow[t]{2}{*}{$\begin{array}{l}\text { Air mass prior rainfall } \\
(\mathrm{mm})\end{array}$} & \multicolumn{2}{|c|}{ Local surface } & \multicolumn{2}{|c|}{$\begin{array}{l}\text { Surface level at } \\
\text { moisture source }\end{array}$} \\
\hline & & & & & & & $\begin{array}{l}\text { Temp } \\
\left({ }^{\circ} \mathrm{C}\right)\end{array}$ & $\begin{array}{l}\text { Rel. Hum. } \\
(\%)\end{array}$ & $\begin{array}{l}\text { Rel. Hum. } \\
(\%)\end{array}$ & $\begin{array}{l}\text { Temp. } \\
\left({ }^{\circ} \mathrm{C}\right)\end{array}$ \\
\hline NW & 4 & $4.37(3.47)$ & $-2.68(1.27)$ & $0.49(9.21)$ & $21.89(1.20)$ & 12.64 & 9.69 & 74.73 & 31.38 & 29.32 \\
\hline $\mathrm{NE}$ & 12 & 11.71(7.91) & $-4.37(1.68)$ & $-18.31(13.69)$ & 16.68(2.99) & 28.99 & 16.08 & 83.94 & 56.02 & 22.93 \\
\hline ENE & 25 & $18.00(27.51)$ & $-6.20(2.72)$ & $-33.61(22.62)$ & $15.99(3.42)$ & 24.34 & 16.63 & 81.52 & 68.13 & 21.02 \\
\hline SE & 30 & $15.55(22.17)$ & $-6.93(3.53)$ & $-37.78(29.39)$ & $17.64(4.30)$ & 27.98 & 13.15 & 87.41 & 69.91 & 14.89 \\
\hline S & 19 & $6.52(5.54)$ & $-5.64(3.68)$ & $-27.23(30.28)$ & $17.89(3.01)$ & 27.38 & 12.39 & 90.46 & 72.44 & 14.02 \\
\hline SW & 33 & $7.28(7.13)$ & $-5.24(2.54)$ & $-24.12(18.97)$ & $17.80(4.27)$ & 24.81 & 9.46 & 75.50 & 61.89 & 14.15 \\
\hline W & 23 & $9.03(6.53)$ & $-4.63(2.58)$ & $-18.73(20.84)$ & $18.35(4.15)$ & 23.21 & 9.42 & 79.57 & 52.67 & 19.00 \\
\hline
\end{tabular}



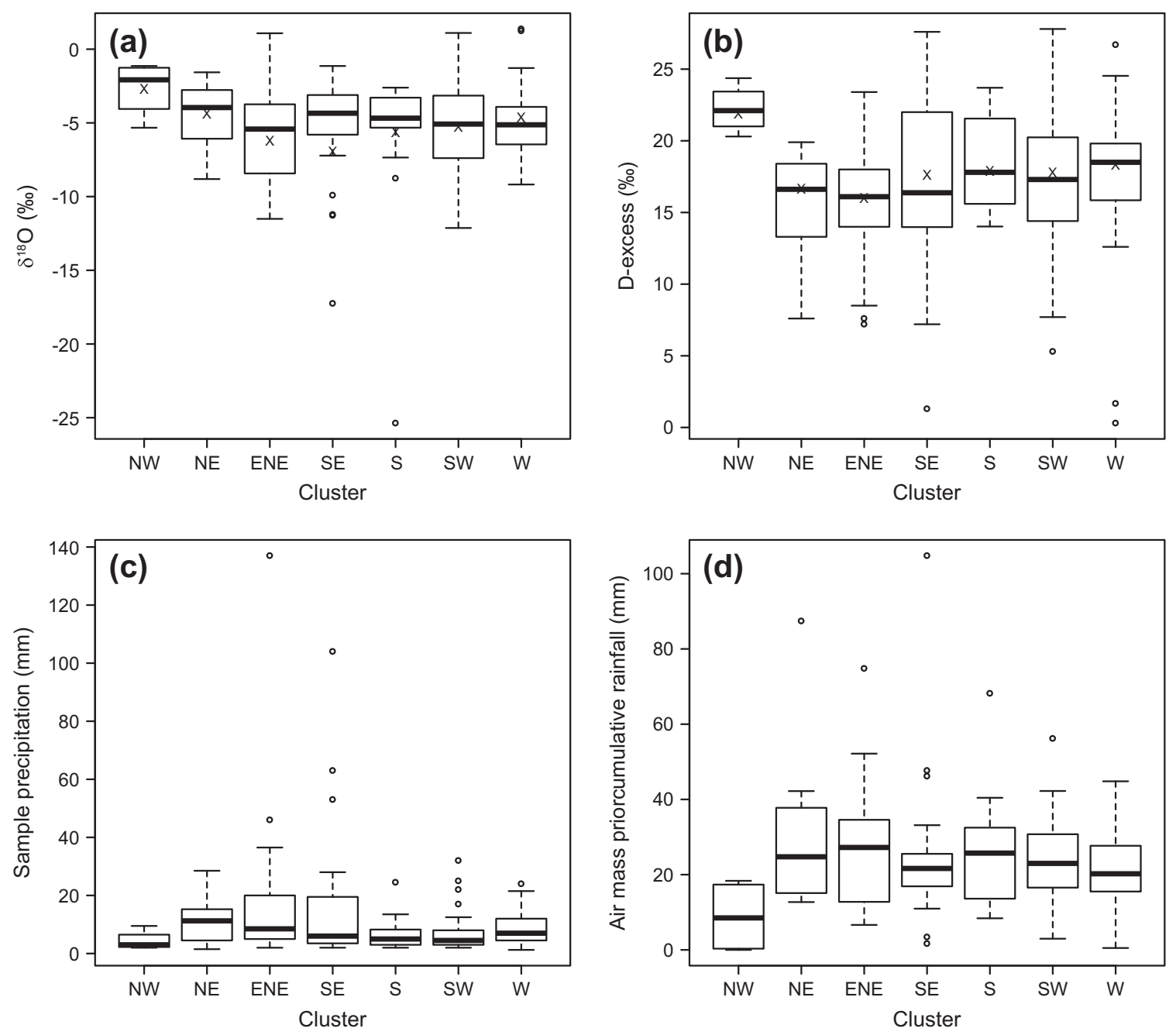

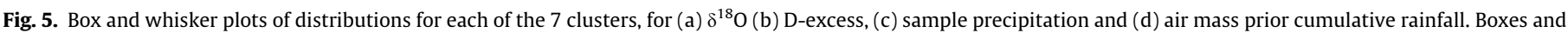
whiskers, as for Fig. 2. The blue crosses represent the cluster precipitation weighted average for (a) $\delta^{18} \mathrm{O}$ and (b) D-excess.

For our samples the correlation coefficient between the cluster precipitation weighted average $\delta^{18} \mathrm{O}$ and the air mass prior cumulative rainfall (i.e. the corresponding two columns in Table 1) was -0.74 ( $p$-value $=0.06)$, indicating that prior rainout has a significant impact on the precipitation $\delta^{18} \mathrm{O}$ when cluster precipitation weighted mean values are considered. On the other hand for the individual samples within the clusters, the correlation of $\delta^{18} \mathrm{O}$ with air mass prior cumulative rainfall for each of the clusters was as follows; northwest $(r=0.13)$, northeast $(-0.25)$, east-northeast $(-0.09)$, southeast $(0.02)$, south $(-0.72)$, southwest $(-0.18)$, and west $(-0.57)$. This indicates that prior rainout, when considered on an individual sample basis, is significant (at $p$-value $=0.004$ ) for the determination of precipitation $\delta^{18} \mathrm{O}$ for air masses arriving from the south and west. Prior rainout had the least correlation with $\delta^{18} \mathrm{O}$ for air masses from the east-northeast and southeast. These two clusters had the largest variability in precipitation amount (Fig. 5c) which would indicate a difference in the dominating processes e.g. for the small events below cloud processes may affect the isotopic composition, which may not impact large and widespread precipitation events.

The main conclusion that can be drawn from the analysis in this section is that when the precipitation weighted average values are calculated for each cluster, a significant relationship exists between the cluster average $\delta^{18} \mathrm{O}$ value and the cluster average air mass prior cumulative rainfall. This is not surprising as using the average value reduces the scatter due to variability of individual precipitation events as a number of processes, during the entire history of the water vapour and the mixing with additional moisture acquired in transit, affect the final isotopic composition of the precipitation (Noone and Simmonds, 2002b). However, significant correlation exists, for individual samples, between air mass prior cumulative rainfall and the isotopic composition of the precipitation when the moisture was sourced south or west of the site.

\subsubsection{D-excess distribution with back trajectory clusters}

The conditions at the moisture source can have considerable impact on the D-excess in precipitation. Both Gat et al. (2003) and Froehlich et al. (2002) showed that D-excess in precipitation was high when moisture was sourced in low relative humidity over the Mediterranean Sea. Using an oceanic global circulation model Xu et al. (2012) determined that D-excess for oceanic surface waters showed little variability for the Australian region, indicating that variations in surface water composition would not contribute greatly to the D-excess in precipitation. However, Guan et al. (2013) used a an empirical model based on sea surface temperature and near surface relative humidity (Uemura et al., 2008) to estimate D-excess in water vapour over oceans which predicted lower D-excess over the Southern Ocean (relative to the Pacific and Indian Oceans) both in summer and winter. 
Here we investigate whether this variation in D-excess for different oceanic sources is reflected in precipitation. The distributions of D-excess within each cluster are presented in Fig. 5b together with the precipitation weighted average D-excess (blue crosses in Fig. 5 with values included in Table 1). The cluster median D-excess was close to the precipitation weighted cluster average D-excess for most clusters. A t-test showed that the arithmetic mean D-excess value of the northwest cluster was significantly different from all other clusters ( $p$-value $=0.01$ ), while the arithmetic mean D-excess of the south cluster was also significantly different $(p$-value $=0.04))$ from the arithmetic means of the NE, ENE and NW clusters. The D-excess in the precipitation did not reflect the D-excess in water vapour over the ocean from where the moisture was sourced (i.e. when comparing to estimated values as presented in Guan et al., 2013), indicating other processes dominate, e.g. mixing with other moisture sources along the air mass trajectory, moisture recycling, in-cloud processes and below-cloud re-evaporation.

The average D-excess values recorded at Mt Werong are higher than the global average of $\sim 10 \%$; however this is characteristic of the Sydney region (Hughes and Crawford, 2013). The D-excess of moisture re-evaporated from the land surface during the daytime is predicted to be higher than oceanic vapour (Simonin et al., 2013; Welp et al., 2012), so this high D-excess may reflect a larger land surface contribution to the regional moisture budget. The Sydney Basin is characterised by eucalypt forest and grassland which may contribute to the local moisture budget through evapotranspiration as air parcels travel over the land surface. Orographic uplift of onshore air masses travelling close to the surface over the moist forested environment of the Lake Burragorang catchment may enhance the contribution of terrestrial moisture into precipitation at Mt Werong.

\subsubsection{Oceanic vs continental moisture sources}

The estimated proportion of moisture sourced from each of the regions in Fig. 4 for each of the clusters is presented in Table 2. Generally the larger the percentage of moisture sourced over land the more enriched the precipitation weighted average $\delta^{18} \mathrm{O}$ values for the cluster. This may be attributed to an enriched moisture source from evapotranspiration (Zimmermann et al., 1967; White and Gedzelman, 1984; Barnes and Allison, 1988; Wang and Yakir, 2000; Jasechko et al., 2013).

To investigate the difference between moisture sourced over land and over the ocean, samples with greater than $80 \%$ moisture derived from the land surface were compared to those with $>80 \%$ of moisture sourced from the ocean. The precipitation weighted average $\delta^{18} \mathrm{O}$ was $-3.5 \%$ (standard deviation of $2.1 \%$ ) for the samples where the majority of the moisture was of a land surface origin and $-7.1 \%$ (standard deviation of $3.7 \%$ ) for those dominated by an ocean moisture source, which is consistent with Simonin et al., 2013. A number of meteorological variables are also compared for the source conditions and are presented in Table 3. For moisture sourced from the land surface the relative humidity at the moisture source was lower and the temperature greater than

\section{Table 2}

Estimated percentage of moisture sourced from each of the regions identified in Fig. 4, for samples in each of the clusters. Values greater than $10 \%$ are presented in bold.

\begin{tabular}{lllllll}
\hline Region & 1 & 2 & 3 & 4 & 5 & 6 \\
\hline NW & 3.7 & 3.7 & 0.0 & 0.0 & 0.8 & $\mathbf{9 1 . 8}$ \\
NE & 0.7 & $\mathbf{2 6 . 4}$ & 6.4 & 2.6 & 0.9 & $\mathbf{6 3 . 0}$ \\
ENE & 0.0 & $\mathbf{4 0 . 1}$ & $\mathbf{1 1 . 1}$ & 3.3 & 0.2 & $\mathbf{4 5 . 3}$ \\
SE & 0.2 & $\mathbf{2 0 . 4}$ & $\mathbf{4 4 . 1}$ & $\mathbf{2 0 . 4}$ & 0.1 & $\mathbf{1 4 . 8}$ \\
S & 0.0 & 6.2 & $\mathbf{4 8 . 4}$ & $\mathbf{3 2 . 4}$ & 0.0 & $\mathbf{1 3 . 0}$ \\
SW & 0.0 & 2.3 & 5.8 & $\mathbf{3 0 . 1}$ & 0.1 & $\mathbf{5 1 . 7}$ \\
W & 1.3 & 4.8 & 1.1 & $\mathbf{2 0 . 2}$ & 3.2 & $\mathbf{6 9 . 4}$ \\
\hline
\end{tabular}

Table 3

Average of selected variables for the two groups of samples; the first group where $80 \%$ or more of the moisture was sourced over land and the second group where $80 \%$ or more of the moisture was sourced over the ocean.

\begin{tabular}{lll}
\hline & $\geqslant 80 \%$ Land & $\geqslant 80 \%$ Ocean \\
\hline$N$ & 22 & 54 \\
$N$ winter & 5 & 21 \\
$N$ summer & 8 & 15 \\
Temperature at moisture source $\left({ }^{\circ} \mathrm{C}\right)$ & 23.8 & 13.3 \\
Relative humidity at the moisture source $(\%)$ & 46.6 & 72.5 \\
Average precipitation amount $(\mathrm{mm})$ & 12 & 10 \\
Air mass prior cumulative rainfall $(\mathrm{mm})$ & 18.8 & 23.5 \\
$\delta^{18}$ O $(\%)$ & -3.5 & -7.1 \\
D-excess & 17.3 & 17.6 \\
\hline
\end{tabular}

at the ocean source. Interestingly there is no significant difference in the D-excess of these two groups of samples which may have been expected due to moisture re-cycling from the land surface. One factor that may attribute to this is the important role of mixing in the air masses as they travel from the ocean, overland, to the collection site (see Section 3.2.2).

\subsection{Variability due to synoptic weather systems}

Scholl et al. (2009) classified event based precipitation samples, from sites in eastern Puerto Rico, by prevailing weather systems (e.g. tropical storms, low pressure systems, high pressure systems, troughs, fronts, etc.). Further, they correlated the isotopic composition in precipitation with the maximum altitude of precipitation within the cloud and the in-cloud atmospheric temperature and found that isotopically depleted precipitation was associated with low pressure systems and convective systems, for which condensation may occur over a large vertical distance (Guan et al., 2013). Precipitation substantially depleted in $\delta^{18} \mathrm{O}$ and $\delta^{2} \mathrm{H}$ was associated with large low pressure systems. On the other hand the winter precipitation (occurring from high pressure systems and frontal systems) was isotopically enriched. They discussed that clouds associated with high pressure systems reached lower altitudes than in the case of low pressure systems, hence the condensation temperature (which has an impact on the isotopic composition of precipitation; Dansgaard, 1964; Clark and Fritz, 1997) was higher for high pressure systems. High pressure systems may also contain a larger proportion of land surface recycled moisture. Windhorst et al. (2012) also found higher $\delta^{18} \mathrm{O}$ values in precipitation associated with trade winds.

Other studies of low pressure cyclonic systems include Baldini et al. (2010), Gedzelman and Lawrence (1990), Gedzelman et al. (2003) and Sinclair et al. (2013). Sinclair et al. (2013) found that low $\delta^{2} \mathrm{H}$ values were associated with precipitation from a strengthened trough of low pressure around Antarctica. Large spatial variability in precipitation isotopic values was seen around cyclonic systems by Gedzelman and Lawrence (1990) and Gedzelman et al. (2003), which is also consistent with a large range in $\delta^{18} \mathrm{O}$ values found in a study from Irish (Dublin) precipitation events resulting from cyclonic weather systems (Baldini et al., 2010).

Here we investigate the isotopic composition at Mt Werong based on the synoptic weather system associated with the precipitation event. The composite MSLPs for each synoptic weather classification are shown in Fig. 6. The number of samples, by season, for each classification is presented in Table 4, showing that the ECL systems occurred more frequently in winter, post frontal precipitation occurred more often in autumn and winter, whilst inland troughs were more frequent in spring and summer.

The distributions of $\delta^{18} \mathrm{O}$, D-excess, precipitation amount, and air mass prior cumulative rainfall for each synoptic system are presented in Fig. 7. Precipitation amount weighted values are 

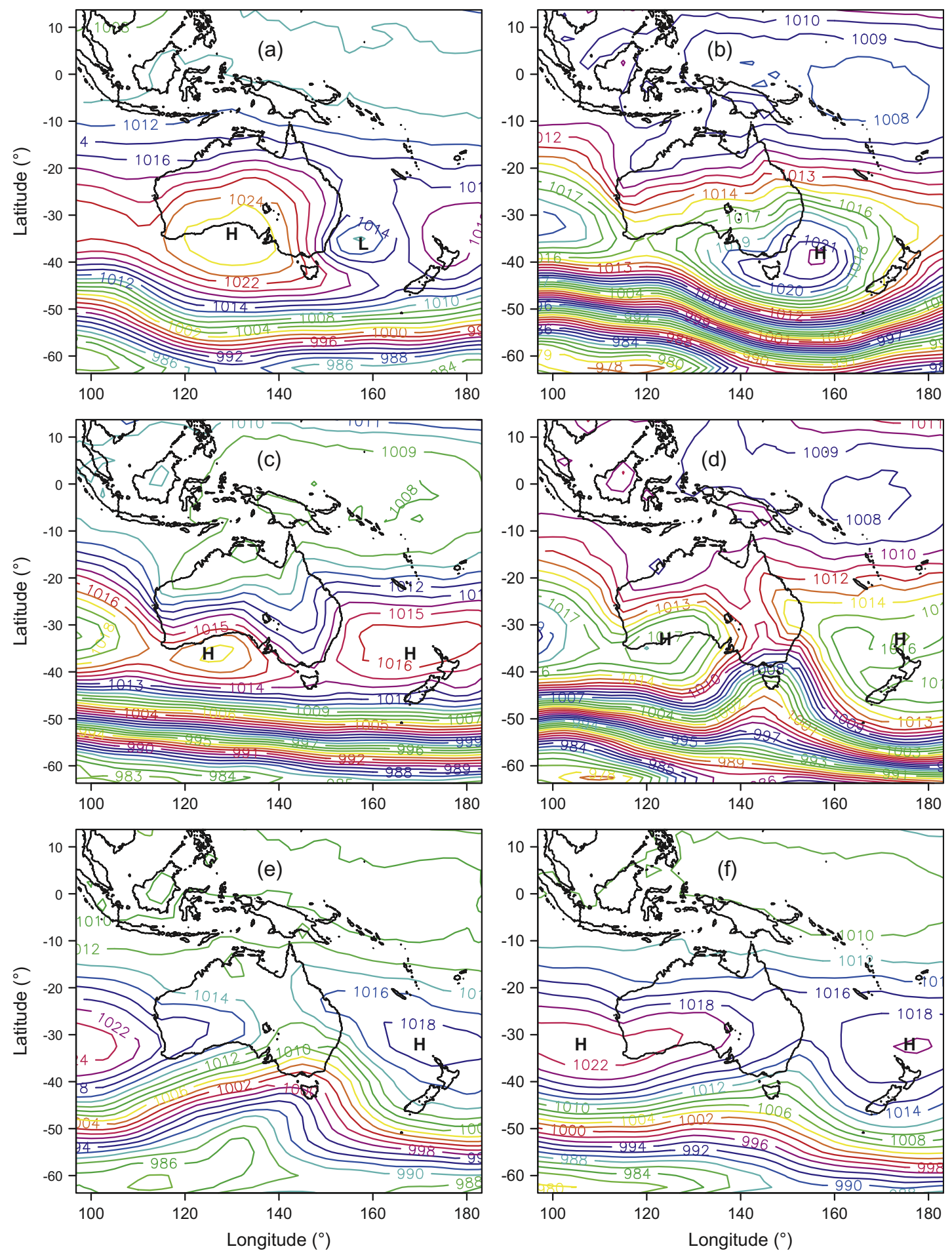

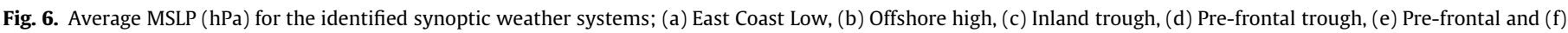
Post-frontal.

Table 4

The number of samples classified in each synoptic weather system, for each season.

\begin{tabular}{lcccc}
\hline System & Autumn & Winter & Spring & Summer \\
\hline East coast low & 0 & 5 & 1 & 0 \\
Offshore high & 7 & 7 & 3 & 7 \\
Inland trough & 9 & 8 & 15 & 27 \\
Pre-frontal trough & 1 & 4 & 1 & 4 \\
Pre-frontal & 1 & 7 & 5 & 2 \\
Post-frontal & 10 & 15 & 5 & 2 \\
\hline
\end{tabular}

presented in Table 5. Each weather system had moisture sourced from more than one of the identified classification in Table 1 . The mean $\delta^{18} \mathrm{O}$ was similar for all weather systems except ECLs, which were significantly more depleted $(p$-value $=0.05$ ) and showed the largest variability, consistent with other studies (Gedzelman and Lawrence, 1990; Gedzelman et al., 2003; Baldini et al., 2010). Further, it has been reported that the impact of the ECL systems at a particular location is dependent on the location of the ECL's centre over the Tasman Sea (Speer et. al., 2009), which may explain the 

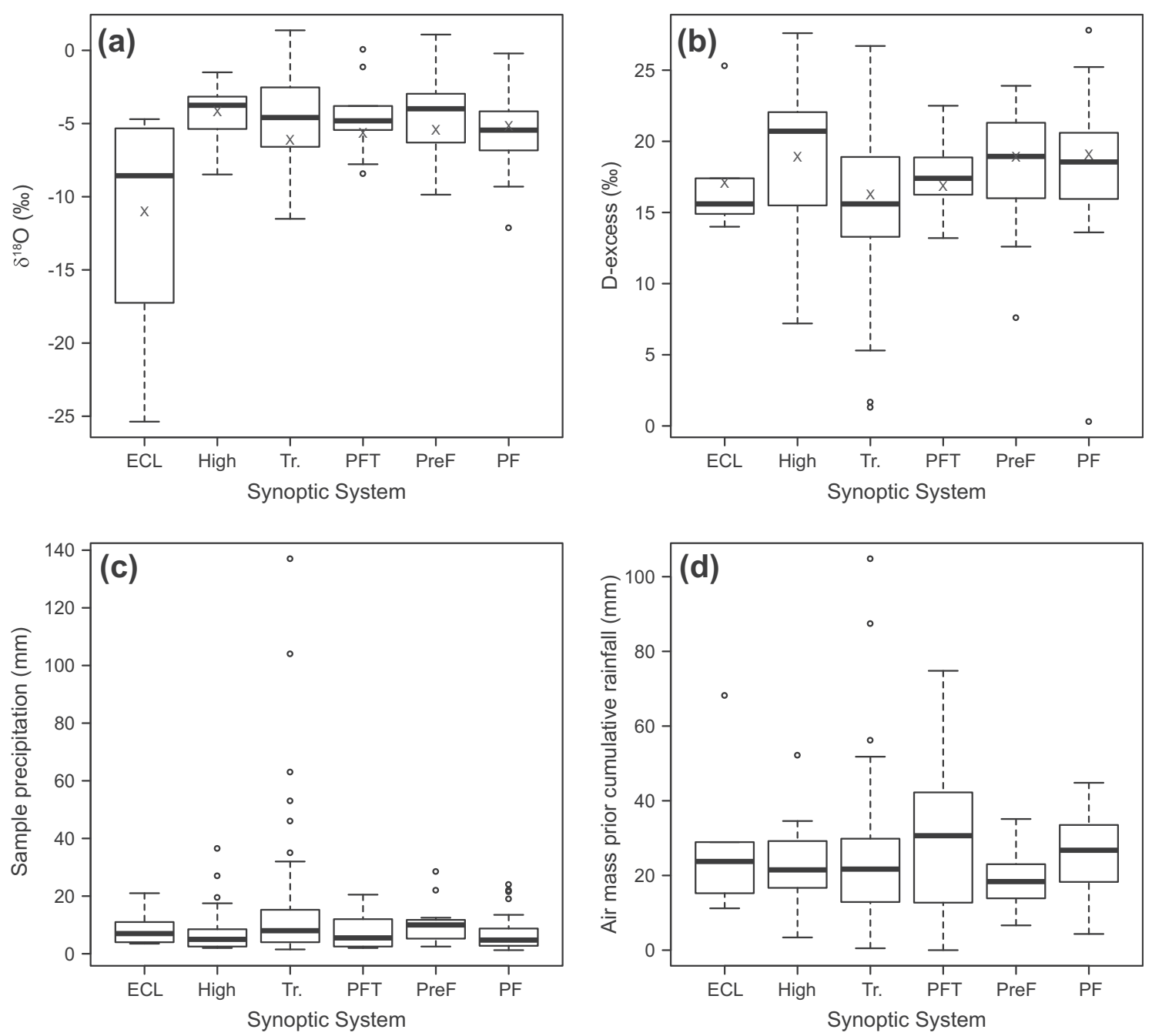

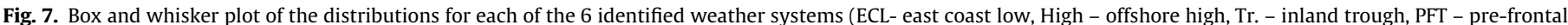

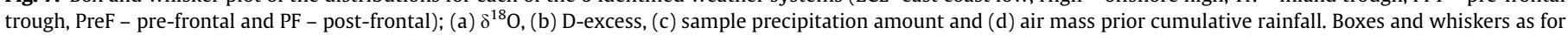
Fig. 2. The blue crosses in (a) and (b) represents the precipitation weighted average value of $\delta^{18} \mathrm{O}$ and D-excess, respectively, for each system.

large variability for $\delta^{18} \mathrm{O}$ values for these systems. Back trajectories corresponding to precipitation from the ECL systems were classified in either the SE, S or W clusters. The correlation coefficient between $\delta^{18} \mathrm{O}$ and the distance from the centre of the ECL to the measurement site was $0.62(p$-value $=0.18)$. However, a more significant correlation was found between the $\delta^{18} \mathrm{O}$ of the samples and the air mass prior cumulative rainfall $(r=-0.9$ with $p$-value $=0.01$ ), whereas the correlation coefficient between $\delta^{18} \mathrm{O}$ and sample precipitation amount was only 0.12 . These results indicate that the climatology of ECL systems could impact upon long term trends in the $\delta^{18} \mathrm{O}$ of the precipitation input for the Sydney region. The impact of tropical cyclone rainfall on low-latitude paleoclimatology has been discussed in Frappier (2013), i.e. the depleted $\delta^{18} \mathrm{O}$ values associated with these systems can be transferred to the stalagmite oxygen isotope records, but in the process they can mask major El Nino events.

A correlation coefficient of $-0.52(p$-value $=0.12)$ was found between $\delta^{18} \mathrm{O}$ and both the air mass prior cumulative rainfall and precipitation at the site, for the pre-frontal trough systems, indicating that large scale rainout has an impact on the $\delta^{18} \mathrm{O}$ of precipitation from these systems. The correlation coefficients between $\delta^{18} \mathrm{O}$ and air mass prior cumulative rainfall were much smaller for the other systems, i.e. offshore high $(r=0.06)$, inland troughs $(-0.1)$, pre-frontal $(-0.25)$, and post frontal $(-0.33)$, indicating that rainout was not the major driver of $\delta^{18} \mathrm{O}$ variability for these systems.
At Mt Werong higher median $\delta^{18} \mathrm{O}$ values of precipitation were also associated with precipitation from high pressure systems and pre-frontal systems (Fig. 7), as found in other studies (see first paragraph in this section).

Besides the ECLs, all systems showed large D-excess variability. When only the inland troughs and post-frontal systems are considered, on average the D-excess results for the Sydney region reflect the finding of Guan et al. (2013) for Adelaide, where the post-frontal systems result in higher precipitation D-excess than the inland troughs. However, for Sydney the D-excess for the inland troughs had a high variability (Fig. 7). Inland troughs are often associated with thunderstorms, ( $42 \%$ of the samples in this case, as reported by the local observer) from convective systems which are known to be complex and inhomogeneous (Dansgaard, 1964; Bony et al., 2008). This was also evident in the large variability in the precipitation amount for these systems (Fig. 7c). Higher median D-excess values were associated with precipitation from high pressure systems, consistent with findings by Windhorst et al. (2012) for a study in Ecuador, which they attributed to moisture re-cycling.

\subsection{Seasonal isotopic variability}

To obtain an indication of what conditions result in isotopic depletion and enrichment in summer and winter the $10 \%$ of most depleted and most enriched samples have been analysed for each 
season. The back trajectories corresponding to those hours for which precipitation was recorded at the site are presented in Fig. 8, where more back trajectories were calculated for the depleted groups, due to longer lasting events.

Analysis of the moisture source regions presented in Table 6, showed that the moisture for winter depleted events was largely derived from off the east coast (80.4\% from regions 2 and 3 ) and the Southern Ocean (12.1\% for region 4$)$, whilst the summer depleted events illustrated an east coast source $(57.8 \%$ - regions 2 and 3 combined) and a continental evapotranspiration source (34.8\% - region 6). Moisture for the enriched events showed a large contribution from continental evapotranspiration, 66.6\% and 39.9\% for winter and summer, respectively. Winter enriched samples also showed a moisture contribution from region $2(2.3 \%), 3(9.5 \%)$ and $4(12.8 \%)$, indicating an increasing moisture contribution moving from north east (warmer SST) of the site to the Southern Ocean (cooler SST), which may result in a decrease in D-excess (Uemura et al., 2008), evident from Table 6. On the other hand, summer enriched events showed the opposite trend with a relatively small contribution from the Southern Ocean (region $4-0.3 \%$ ), and an increasing contribution from region 3 (19.1\%) to region 2 (40.7\%).

The composite MSLP maps associated with the depleted and enriched events are shown in Fig. 9. These maps give an indication of the types of prevailing synoptic weather systems that produce the precipitation. The winter depleted events show a cyclonic low pressure system near the east coast, which is a characteristic of
ECLs, with moisture transported from south and southeast of the site. The summer depleted events show an inland region of low pressure between two high pressure systems. Inland troughs would draw moisture down from a warmer moisture source to the north of the site (moisture region 2 and over land, see Table 6), converging towards the trough where moist air would experience convection.

The air mass prior cumulative rainfall was higher for both summer and winter depleted samples, indicating depletion was most likely due to greater rainout prior to the site.

Both the summer and winter enriched events do not show clear synoptic patterns that would be associated with large precipitation events, which is reflected in the precipitation amount. The winter events show evidence of baroclinicity along the east coast that could be associated with the passing of a cold front, whilst summer events show a high pressure system located in the Tasman Sea. The enriched events could be associated with local short duration and low intensity precipitation events.

Both the winter and summer most depleted samples had a similar D-excess, reflecting the similar relative humidity at the moisture source. The winter most enriched samples had a high D-excess indicative of evaporation in low humidity conditions (Froehlich et al., 2002), supported by the precipitation weighted relative humidity at the moisture source of $45 \%$ and also about $66 \%$ of the moisture was sourced over land (Table 6 ). On the other hand the summer most enriched samples had a low D-excess
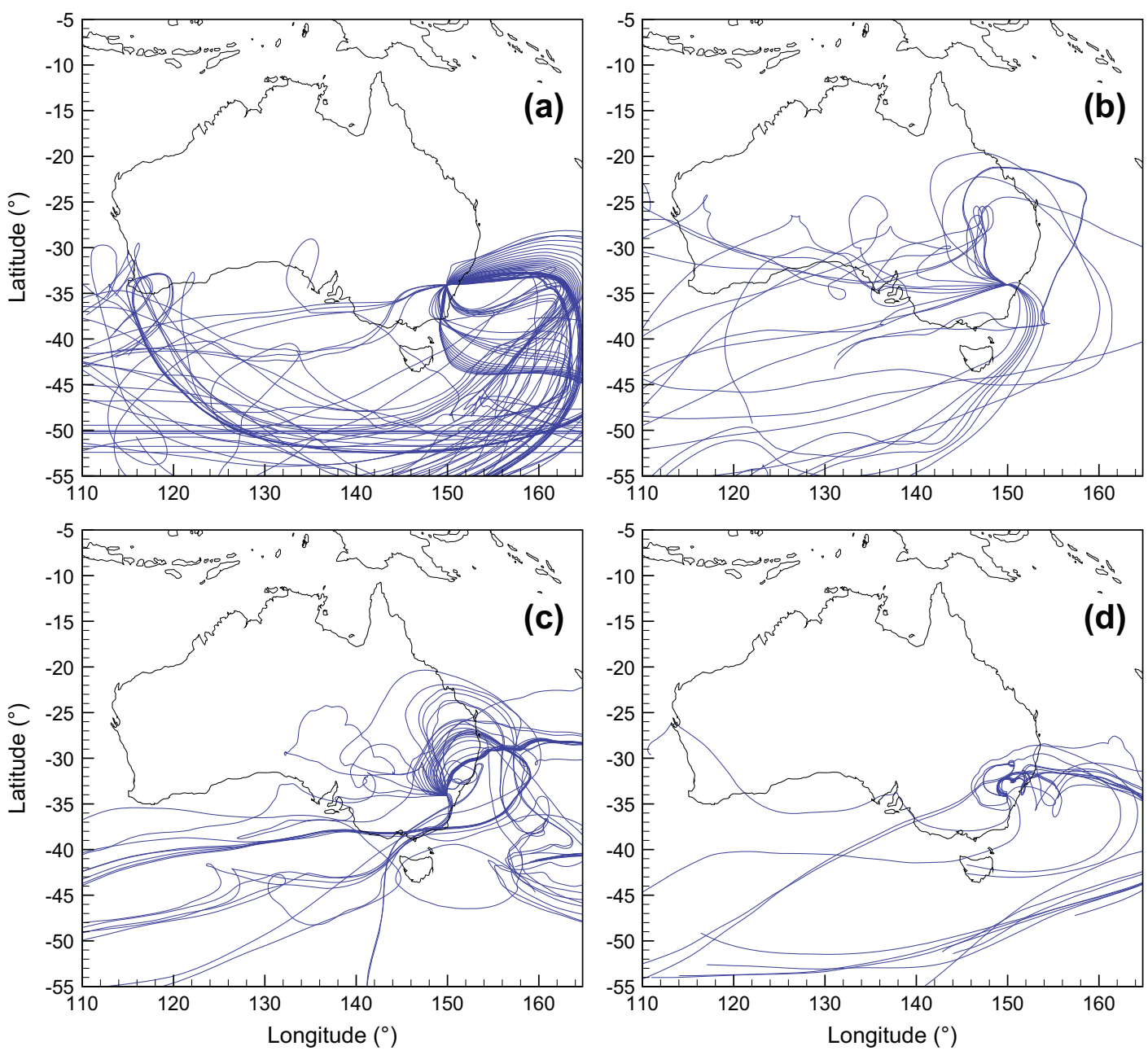

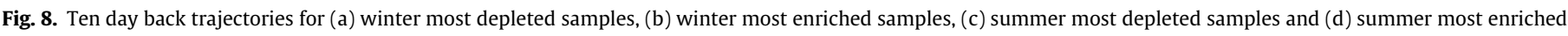
samples. 
Table 5

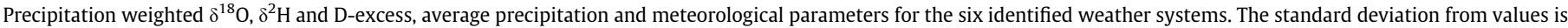
also presented in brackets.

\begin{tabular}{|c|c|c|c|c|c|c|c|c|c|c|}
\hline \multirow[t]{2}{*}{ System } & \multirow[t]{2}{*}{$N$} & \multirow[t]{2}{*}{$\begin{array}{l}\text { Precipitation } \\
(\mathrm{mm})\end{array}$} & \multirow[t]{2}{*}{$\delta^{18} \mathrm{O}(\%)$} & \multirow[t]{2}{*}{$\delta^{2} \mathrm{H}(\%)$} & \multirow[t]{2}{*}{$\begin{array}{l}\text { D-excess } \\
(\% o)\end{array}$} & \multirow[t]{2}{*}{$\begin{array}{l}\text { Air mass prior rainfall } \\
(\mathrm{mm})\end{array}$} & \multicolumn{2}{|c|}{ Local surface } & \multicolumn{2}{|c|}{$\begin{array}{l}\text { Surface level at } \\
\text { moisture source }\end{array}$} \\
\hline & & & & & & & $\begin{array}{l}\text { Temp. } \\
\left({ }^{\circ} \mathrm{C}\right)\end{array}$ & $\begin{array}{l}\text { Rel. Hum. } \\
(\%)\end{array}$ & $\begin{array}{l}\text { Rel. Hum. } \\
(\%)\end{array}$ & $\begin{array}{l}\text { Temp. } \\
\left({ }^{\circ} \mathrm{C}\right)\end{array}$ \\
\hline ECL & 6 & $8.91(6.53)$ & $-11.00(5.65)$ & $-70.95(46.01)$ & $17.09(3.15)$ & 24.46 & 4.50 & 90.67 & 73.05 & 10.27 \\
\hline Offshore high & 24 & $8.02(8.96)$ & $-4.15(2.00)$ & $-14.30(14.03)$ & $18.93(4.94)$ & 22.60 & 15.23 & 70.73 & 65.46 & 18.21 \\
\hline Inland trough & 59 & $15.85(23.74)$ & $-6.13(3.03)$ & $-32.74(24.65)$ & $16.30(3.71)$ & 25.69 & 15.18 & 87.11 & 66.83 & 17.95 \\
\hline $\begin{array}{c}\text { Pre-frontal } \\
\text { trough }\end{array}$ & 10 & $8.35(7.23)$ & $-5.65(1.85)$ & $-28.34(15.54)$ & $16.88(1.66)$ & 41.95 & 14.02 & 82.34 & 66.50 & 21.36 \\
\hline Pre-frontal & 15 & $10.26(6.98)$ & $-5.45(2.55)$ & $-24.71(20.10)$ & $18.89(3.52)$ & 20.59 & 9.18 & 77.45 & 58.25 & 19.34 \\
\hline Post-frontal & 32 & $7.13(6.26)$ & $-5.15(2.25)$ & $-22.12(24.65)$ & $19.06(3.71)$ & 26.18 & 8.20 & 77.78 & 56.89 & 15.92 \\
\hline
\end{tabular}
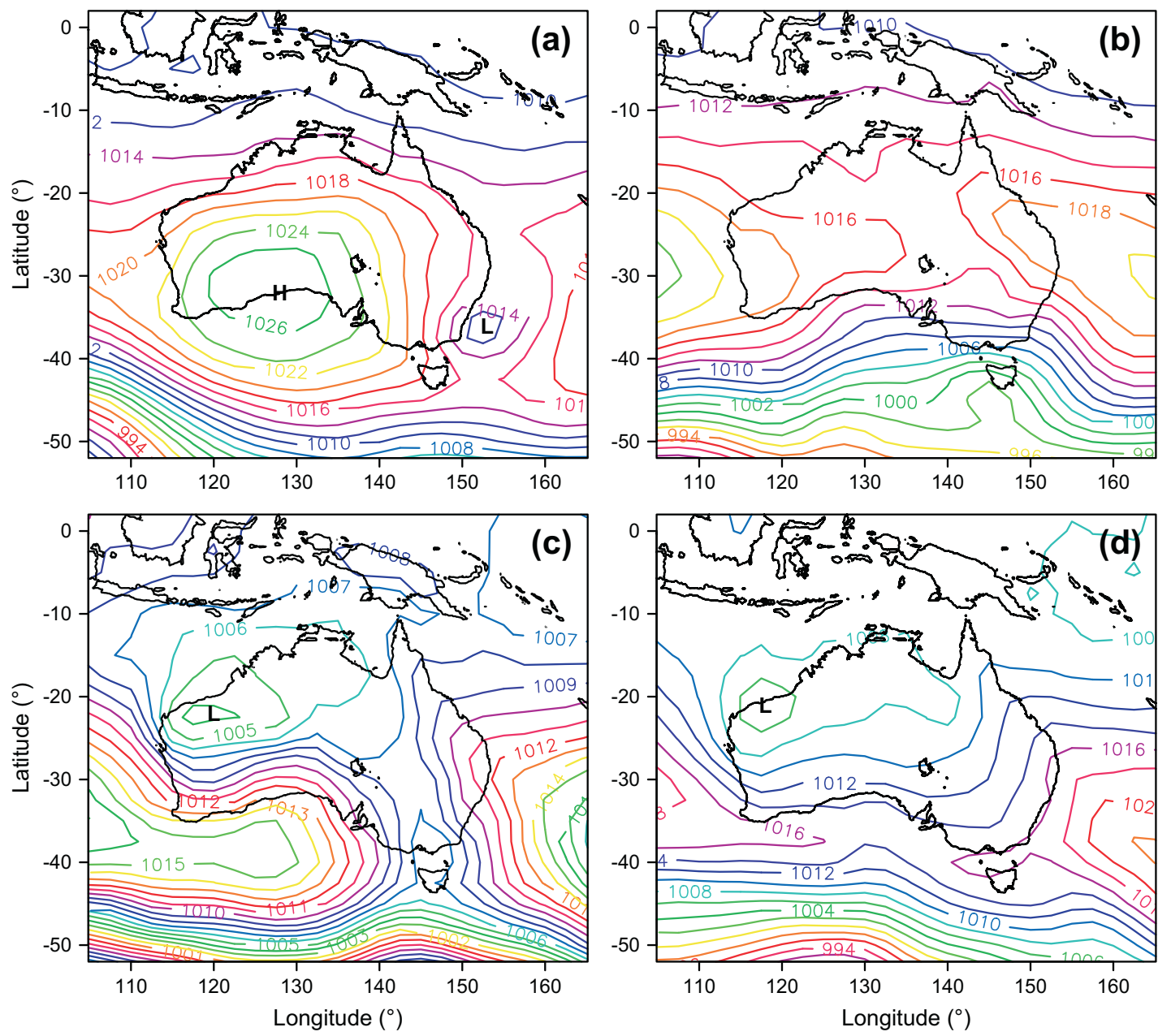

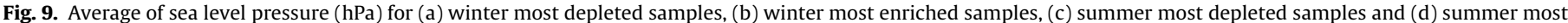
enriched samples.

indicative of re-evaporation of rain drops below the cloud (Froehlich et al., 2002), supported by the high local surface temperature and low local surface relative humidity (Table 6). There was little difference between the conditions at the moisture source for the summer depleted and enriched samples. Also the average sample precipitation amount for the isotopically enriched groups was lower than for the isotopically depleted group. The usefulness of D-excess is illustrated when the most enriched samples were analysed, i.e. high D-excess for the winter samples indicating evaporation in low humidity conditions and low D-excess in summer (coupled with the higher $\delta^{18} \mathrm{O}$ ) indicating the possible re-evaporation below the cloud.

\section{Conclusions}

The stable isotope composition of single event precipitation at Mt Werong was analysed. A better correlation coefficient was seen between the precipitation $\delta^{18} \mathrm{O}$ and the air mass prior cumulative rainfall $(r=-0.25)$ than between precipitation $\delta^{18} \mathrm{O}$ and the amount of precipitation at the site $(r=-0.15)$.

Back trajectory cluster analysis showed no significant difference in the arithmetic mean of $\delta^{18} \mathrm{O}$ between the clusters, aside from trajectories arriving over land from the northwest. This may be an indication that the conditions over the oceanic moisture sources are not sufficiently different to cause large changes in the isotopic 
Table 6

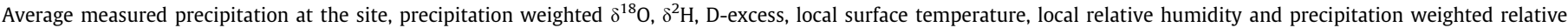

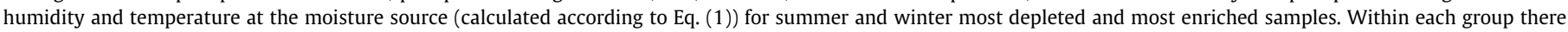
were five samples. Also included is the\% of moisture sourced from each region identified in Fig. 4 (there was no contribution from region 1).

\begin{tabular}{|c|c|c|c|c|c|c|c|c|c|c|c|c|c|}
\hline & \multirow[t]{2}{*}{$\begin{array}{l}\text { Av. Precip. } \\
(\mathrm{mm})\end{array}$} & \multirow[t]{2}{*}{$\begin{array}{l}\delta^{18} \mathrm{O} \\
(\% o)\end{array}$} & \multirow[t]{2}{*}{$\begin{array}{l}\delta^{2} \mathrm{H} \\
(\% o)\end{array}$} & \multirow[t]{2}{*}{$\begin{array}{l}\text { D-excess } \\
(\% o)\end{array}$} & \multicolumn{2}{|c|}{ Local surface level } & \multicolumn{2}{|c|}{$\begin{array}{l}\text { Surface level at moisture } \\
\text { source }\end{array}$} & \multicolumn{5}{|c|}{$\begin{array}{l}\text { Moisture from each source } \\
\text { region }(\%)\end{array}$} \\
\hline & & & & & $\begin{array}{l}\text { Temp. } \\
\left({ }^{\circ} \mathrm{C}\right)\end{array}$ & $\begin{array}{l}\text { Rel. Hum. } \\
(\%)\end{array}$ & $\begin{array}{l}\text { Rel. Hum. } \\
(\%)\end{array}$ & $\begin{array}{l}\text { Temp. } \\
\left({ }^{\circ} \mathrm{C}\right)\end{array}$ & 2 & 3 & 4 & 5 & 6 \\
\hline Winter most depleted & 26.9 & -11.96 & -80.00 & 15.65 & 6.13 & 90.22 & 70.58 & 11.86 & 48.5 & 31.9 & 12.1 & 0.0 & 7.5 \\
\hline Winter most enriched & 4.6 & -2.43 & 1.11 & 20.58 & 8.00 & 73.06 & 45.66 & 22.57 & 2.3 & 9.5 & 12.8 & 8.4 & 66.6 \\
\hline $\begin{array}{l}\text { Summer most } \\
\text { depleted }\end{array}$ & 38.0 & -7.35 & -41.82 & 16.97 & 19.38 & 81.71 & 69.53 & 22.00 & 49.4 & 8.4 & 7.4 & 0.0 & 34.8 \\
\hline $\begin{array}{l}\text { Summer most } \\
\text { enriched }\end{array}$ & 10.9 & -1.39 & 0.06 & 11.19 & 22.58 & 50.93 & 66.28 & 21.36 & 40.7 & 19.1 & 0.3 & 0.0 & 39.9 \\
\hline
\end{tabular}

composition at the precipitation site on an individual sample basis due to the dominance of other processes. However, when the cluster precipitation weighted average values were considered a significant relationship existed between the isotopic composition of the precipitation and the air mass prior cumulative rainfall. Further, two distinct moisture sources (land based or oceanic) were identified by selecting those samples with $80 \%$ or more of the moisture sourced over land which were relatively enriched in $\delta^{18} \mathrm{O}$ (with a precipitation weighted average of $-3.5 \%$ ) compared to those samples for which $80 \%$ or more of the moisture was oceanic (with a precipitation weighted average $\delta^{18} \mathrm{O}$ of $-7.1 \%$ ).

Classification by synoptic weather systems showed that the arithmetic mean precipitation $\delta^{18} \mathrm{O}$ for the ECLs was significantly different (lower) from all other systems ( $p$-value $=0.05$ ), and it exhibited a large variability (standard deviation of $5.65 \%$ ), which in turn was dependent on the air mass prior cumulative rainfall and distance from the site to the centre of the low pressure system. The arithmetic mean precipitation $\delta^{18} \mathrm{O}$ values for the other systems were not significantly different. These results indicate that the occurrence of ECL systems is the most likely contributor to long term changes for isotopically depleted precipitation $\delta^{18} \mathrm{O}$ inputs to speleothems or groundwater recharge in the Sydney region. Precipitation resulting from ECL systems, inland troughs and pre-frontal troughs had the lowest precipitation weighted mean D-excess.

Analysis of the summer most depleted and most enriched samples showed the same moisture source regions, however, the more depleted samples were from well-developed synoptic systems from which more precipitation had occurred both at the site and prior to the site. The winter depleted samples were more likely to result from ECLs. Both the summer and winter enriched events could be associated with local short duration and low intensity precipitation events.

\section{Acknowledgements}

We would like to thank Bob Cullen for his dedication and reliability in collecting the samples and recording precipitation data at Mt Werong; Martin Gilmour and James Ray from SCA for providing precipitation data. NCEP Reanalysis data provided by the NOAA/OAR/ESRL PSD Boulder, Colorado, was used in this work and also data from the Australian Bureau of Meteorology. The NOAA Air Resources Laboratory (ARL) made available the HYSPLIT transport and dispersion model and the relevant input files for generation of back trajectories.

\section{Appendix A. Supplementary material}

Supplementary data associated with this article can be found, in the online version, at http://dx.doi.org/10.1016/j.jhydrol.2013. 10.031 .

\section{References}

Araguas-Araguas, L., Froehlich, K., Rozanski, K., 2000. Deuterium and oxygen-18 isotope composition of precipitation and atmospheric moisture. Hydrol. Process. 14 (1341-1355), 9.

Awad, M.A., 1996. Application of stable isotopes (180, D) and geochemistry to study groundwater in Bahareya Oasis, Western Desert. Egypt. Isot. Environ. Health Stud. 32 (1) 87-95.

Baldini, L.M., McDermott, F., Baldini, J.U.L., Fischer, M.J., Mollhoff, M., 2010. An investigation of the controls on Irish precipitation $\delta^{18} \mathrm{O}$ values on monthly and event timescales. Clim. Dyn. 35, 977-993. http://dx.doi.org/10.1007/s00382010-0774-6.

Barnes, C.J., Allison, G.B., 1988. Tracing of water movement in the unsaturated zone using stable isotopes of hydrogen and oxygen. J. Hydrol. 100, $143-176$.

Barras, V.J.L., Simmonds, I., 2008. Synoptic controls upon $\delta^{18} \mathrm{O}$ in southern Tasmanian precipitation. Geophys. Res. Lett. 35, L02707. http://dx.doi.org/ 10.1029/2007GL031835.

Barras, V., Simmonds, I., 2009. Observation and modelling of stable water isotopes as diagnostics of rainfall dynamics over southeastern Australia. J. Geophys. Res. 114, D23308. http://dx.doi.org/10.1029/2009JD012132.

Bigg, G.R., Rohling, E.J., 2000. An oxygen isotope data set for marine waters. J. Geophys. Res. 105 (C4), 8527-8535.

Bony, S., Risi, C., Vimeux, F., 2008. Influence of convective processes on the isotopic composition $\left(\delta^{18} \mathrm{O}\right.$ and $\left.\delta \mathrm{D}\right)$ of precipitation and water vapour in the tropics: radiative-convective equilibrium and tropical Ocean - Global AtmosphereCoupled Ocean-Atmosphere Response Experiment (TOGA-COARE) simulations. J. Geophys. Res. 113, D19305. http://dx.doi.org/10.1029/2008/JD009942.

BOM, 2012. MSLP Maps Sourced from the Australian Bureau of Meteorology, <http://www.bom.gov.au/australia/charts/archive/index.shtml> (accessed 2012).

Burnett, A.W., Mullins, H.T., Patterson, W.P., 2004. Relationship between atmospheric circulation and winter precipitation $\delta^{18} \mathrm{O}$ in central New York State. Geophys. Res. Lett. 31, L22209. http://dx.doi.org/10.1029/2004GL021089.

Clark, I.D., Fritz, P., 1997. Environmental Isotopes in Hydrogeology. CRC Press, Boca Raton.

Dansgaard, W., 1964. Stable isotopes in precipitation. Tellus 16, 436-468.

Draxler, R.R., Rolph, G.D., 2003. Hybrid Single-Particle Lagrangian Integrated Trajectory (HYSPLIT), model, <http://www.arl.noaa.gov/ready/hysplit4.html>.

Dunkerley, D., 2008. Identifying individual rain events from pluviograph records: a review with analysis of data from Australian dryland site. Hydrol. Process. 22, 5024-5036.

Feng, X., Faiia, A.M., Posmentier, E.S., 2009. Seasonality of isotopes in precipitation: a global perspective. J. Geophys. Res. 114, D08116. http://dx.doi.org/10.1029/ 2008JD011279.

Field, R.D., 2010. Observed and modelled controls on precipitation $\delta^{18} \mathrm{O}$ over Europe: from local temperature to the Northern Annular Mode. J. Geophys. Res. 115, D12101. http://dx.doi.org/10.1029/2009JD013370.

Frappier, A.B., 2013. Masking of interannual climate proxy signals by residual tropical cyclone rainwater: evidence and challenges for low-latitude speleothem paleoclimatology. Geochem. Geophys. Geosyst.. http://dx.doi.org/ 10.1002/ggge.20218.

Friedman, I., Harris, J.M., Smith, G.I., Johnson, C.A., 2002. Stable isotope composition of waters in the Great Basin, United States 1. Air-mass trajectories. J. Geophys. Res. 107 (D19), 4400. http://dx.doi.org/10.1029/2001JD000565.

Froehlich, K., Gibson, J.J., Aggarwal, P.K., 2002. Deuterium excess in precipitation and its climatological significance. In: Proc. Study of Environmental Change Using Isotope Techniques, IAEA, Vienna, IAEA-CSP-13/P, pp. 54-66.

Froehlich, K., Kralik, M., Papesch, W., Rank, D., Scheifinger, H., Stichler, W., 2008. Deuterium excess in precipitation of Alpine regions - moisture recycling. Isot. Environ. Health Stud. 44 (1), 61-70.

Gat, J.P., 2000. Atmospheric water balance - the isotopic perspective. Hydrol. Process. 14, 1357-1369.

Gat, RJ. Klein, B., Kushnir, Y, Roether, W. Wernli, H., Yam, R., Shemesh, A. 2003. Isotope composition of air moisture over the Mediterranean Sea: an index of the air-sea interaction pattern. Tellus 55B, 953-965. 
Gat, J.R., Airey, P.L., 2006. Stable water isotopes in the atmosphere/biosphere/ lithosphere interface: scaling from the local to continental scale, under humid and dry conditions. Global Planet. Change 51, 25-33.

Gedzelman, S.D., Lawrence, J.R., 1990. The isotopic composition of precipitation from two extratropical cyclones. Mon. Weather Rev. 118, 495-509.

Gedzelman, S., Lawrence, J., Gamache, J., Black, M., Hindman, E., Black, R., Dunion, J., Willoughby, H., Zhang, X., 2003. Probing hurricanes with stable isotopes of rain and water vapor. Mon. Weather Rev. 131, 1112-1127.

Gröning, M., Lutz, H.O., Roller-Lutz, Z., Kralik, M., Gourcy, L., Pöltenstein, L., 2012. A simple rain collector preventing water re-evaporation dedicated for $\delta^{18} \mathrm{O}$ and $\delta$ ${ }^{2} \mathrm{H}$ analysis of cumulative precipitation samples. J. Hydrol. 448-449, 195-200.

Guan, H., Simmons, C.T., Love, A.J., 2009. Orographic controls on rain water isotope distribution in the Mount Lofty Ranges of South Australia. J. Hydrol. 374, 255 264

Guan, H., Zhang, X., Skrzypek, G., Sun, Z., Xu, X., 2013. Deuterium excess variations of rainfall events in a coastal area of South Australia and its relationship with synoptic weather systems and atmospheric moisture sources. J. Geophys. ResAtmos. 118, 1-16. http://dx.doi.org/10.1002/jgrd.50137.

Hughes, C.E., Crawford, J., 2013. Spatial and temporal variation in precipitation isotopes in the Sydney Basin, Australia. J. Hydrol. 489, 42-55.

International Atomic Energy Agency, 2005. Isotopic Composition of Precipitation in the Mediterranean Basin in Relation to Air Circulation Patterns and Climate. IAEA-TECDOC-1453, IAEA, Vienna, ISBN 92-0-105305-1.

Jacob, H., Sonntag, C., 1991. An 8-year record of the seasonal variation of ${ }^{2} \mathrm{H}$ and ${ }^{18} \mathrm{O}$ in atmospheric water vapour and precipitation at Heidelberg, Germany. Tellus 43B, 291-300.

Jasechko, S., Sharp, Z.D., Gibson, J.J., Birks, S.J., Yi, Y., Pawcett, P.J., 2013. Terrestrial water fluxes dominated by transpiration. Nature 496, 347-350. http:// dx.doi.org/10.1038/nature11983.

Kalnay, E., Kanamitsu, M., Kistler, R., et al., 1996. The NCEP/NCAR 40-year reanalysis project. Bull. Amer. Meteor. Soc. 787, 437-470, http://www.esrl.noaa.gov/psd/ data/reanalysis/reanalysis.shtml.

Kottek, M., Grieser, J., Beck, C., Rudole, B., Rubel, F., 2006. World Map of KöppenGeiger climate classification updated. Meteor. Z. 15, 259-263.

Lachniet, A.S., 2009. Sea surface temperature control on the stable isotopic composition of rainfall in Panama. Geophys. Res. Lett. 36, L03701. http:// dx.doi.org/10.1029/2008GL036625.

Lykoudis, S.P., Kostopoulou, E., Argiriou, A.A., 2010. Stable isotopic signature of precipitation under various synoptic classifications. Phys. Chem. Earth 35, 530 535.

Majoube, M., 1971. Fractionnement en ${ }^{18} \mathrm{O}$ et en deuterium entre l'eau et sa vapour. J. Chem. Phys. 10, 1423-1428.

Manfroi, O.J., Koichiro, K., Nobuaki, T., Masakazu, S., Nakagawa, M., Nakashizuka, T., Chong, L., 2004. The stemflow of trees in a Bornean lowland tropical forest. Hydrol. Process. 18, 2455-2474.

Matthews, C., Geerts, B., 1995. Characteristic thunderstorm distribution in the Sydney area. Aust. Meteorol. Mag. 44, 127-138.

McDermott, F., 2004. Paleo-climate reconstruction from stable isotope variations in speleothems: a review. Quaternary Sci. Rev. 23, 901-918.

Merlivat, L., Jouzel, J., 1979. Global climatic interpretation of the deuterium-oxygen 18 relationship for precipitation. J. Geophys. Res. 84 (C8), 5029-5033.

Noone, D., Simmonds, I., 2002a. Associations between $\delta 180$ of water and climate parameters in a simulation of atmospheric circulation for 1979-95. J. Climate 15, 3150-3168.

Noone, D., Simmonds, I., 2002b. Annular variations in moisture transport mechanisms and the abundance of $\delta^{18} \mathrm{O}$ in Antarctic snow. J. Geophys. Res. 107, 4742, http://dx.doi.org/10.1029/2002JD002262.

Peng, T.R., Wang, C.H., Huang, C.C., Fei, L.Y., Chen, C.T.A., Hwong, J.L., 2010. Stable isotopic characteristic of Taiwan's precipitation: a case study of western Pacific monsoon region. Earth Planet. Sci. Lett. 289, 357-366. http://dx.doi.org/ 10.1016/j.epsl.2009.11.024.

Pogson, R.E., Osborne, R.A.L., Colchester, D.M., Cendon, D.I., 2011. Sulfate and Phosphate Speleothems at Jenolan Caves, New South Wales, Australia. Acta Carsologica 40 (2), 239-254.

Reynolds, R.W., Rayner, N.A., Smith, T.M., Stokes, D.C., Wang, W., 2002. An improved in situ and satellite SST analysis for climate. J. Climate 15 (13), 1609-1625.

Risi, C., Bony, S., Vimeux, P., 2008. Influence of convective processes on the isotopic composition $\left(\delta^{18} \mathrm{O}\right.$ and $\left.\delta \mathrm{D}\right)$ of precipitation and water vapour in the tropics: 2 . Physical interpretation of the amount effect. J. Geophys. Res. 113, D19306. http://dx.doi.org/10.1029/2008JD009943.
Rozanski, K., Araguas-Araguas, L., Gonfiantini, R., 1993. Isotopic patterns in modern precipitation. In: Swart, P.K., et al. (Eds.), Climate Change in Continental Isotopic Records. Geophys. Monogr. Ser. 78, AGU, Washington, DC, pp. 1-36.

Simonin, K.A., Link, P., Rempe, D., Miller, S., Oshun, J., Bode, C., Dietrich, W.E., Fung I., Dawson, T.E., 2013. Vegetation induced changes in the stable isotope composition of near surface humidity. Ecohydrology. http://dx.doi.org/10.1002/ eco.1420.

Sinclair, K.E., Bertler, N.A.N., Trompetter, W.J., Baisden, W.T., 2013. Seasonality of airmass pathways to coastal antarctica: ramifications for interpreting highresolution ice core records. J. Climate 26, 2065-2076.

Scholl, M.A., Shanley, J.B., Zegarra, J.P., Coplen, T.B., 2009. The stable isotope amount effect: new insights from NEXRAD echo tops, Luquillo Mountains, Puerto Rico. Water Resour. Res. 45, W12407. http://dx.doi.org/10.1029/2008WR007515.

Sjostrom, D.J., Welker, J.M., 2009. The influence of air mass source on the seasona isotopic composition of precipitation, eastern USA. J. Geochem. Explor. 102, $103-112$.

Sodemann, H., Schwierz, C., Wernli, H., 2008. Interannual variability of Greenland winter precipitation sources: lagrangian moisture diagnostic and North Atlantic Oscillation influence. J. Geophys. Res. 113, D03107. http://dx.doi.org/10.1029/ 2007/JD008503.

Speer, M., Geerts, B., 1994. A synoptic-meso- Scale climatology of flash-floods in the Sydney metropolitan area. Aust. Meteorol. Mag. 43, 87-103.

Speer, M.S., Wiles, P., Pepler, A., 2009. Low pressure systems off the New South Wales coast and associated hazardous weather: establishment of a database. Aust. Meteorol. Ocean. 58, 29-39.

Treble, P.C., Budd, W.F., Hope, P.K., Rustomji, P.K., 2005. Synoptic-scale climate patterns associated with rainfall $\delta^{18} \mathrm{O}$ in southern Australia. J. Hydrol. 302, 270 282.

Treble, P.C., Bradley, C., Wood, A., Baker, A., Jex, C.N., Fairchild, I.J., Gaga, M.K. Cowley, J., Azcurra, C., 2013. An isotopic study of flow paths and storage in Quaternary calcarenite, SW Australia: implications for speleothem paleoclimate records. Quaternary Sci. Rev. 64, 90-103.

Trenberth, K.E., 1998. Atmospheric moisture residence times and cycling: implications for rainfall rates and climate change. Climatic Change 39, 667-694.

Uemura, R., Matsui, Y., Yoshimura, K., Motoyana, H., Yoshida, N., 2008. Evidence of deuterium excess in water vapour as an indicator of ocean surface conditions. J. Geophys. Res-Atmos. 113, D19114. http://dx.doi.org/10.1029/2008JD010209.

Vachon, R.W., Welker, J.M., White, W.C., Vaughn, B.H., 2010. Moisture source temperatures and precipitation $\delta^{18} \mathrm{O}$-temperature relationships across the United States. Water Resour. Res. 46, W07523. http://dx.doi.org/10-1029/ 2009WR008558.

Vimeux, F., Masson, V., Jouzel, J., Petit, J.R., Steig, E.J., Stievenard, M., Vaikmae, R. White, J.W.C., 2001. Holocene hydrological cycle changes in the Southern Hemisphere documented in East Antarctic deuterium excess records. Clim. Dyn. 17, 503-513.

Wang, X.F., Yakir, D., 2000. Using stable isotopes of water in evapotranspiration studies. Hydrol. Process. 14, 1407-1421.

Welp, L.R., Lee, X., Kim, K., Griffis, T.J., Billmark, K.A., Baker, J.M., 2008. $\Delta^{18}$ O of water vapour, evapotranspiration and the sites of leaf water evaporation in a soybean canopy. Plant Cell Environ. 31, 1214-1228. http://dx.doi.org/10.1111/j.13653040.2008.01826.x

Welp, L.R., Lee, X., Griffis, T.J., Wen, X.-F., Xiao, W., Li, S., Sun, X., Hu, Z., Val Martin, M., Huang, J., 2012. A meta-analysis of water vapor deuterium-excess in the midlatitude atmospheric surface layer. Global Biogeochem. Cy. 26 (3), GB3021.

White, J.W.C., Gedzelman, D., 1984. The isotopic composition of atmospheric water vapour and the concurrent meteorological conditions. J. Geophys. Res. 89 4937-4939.

Windhorst, D., Waltz, T., Frede, H.-G., Breuer, L., 2012. Impact of elevation and weather patterns on the isotopic composition of precipitation in a tropical montane rainforest. Hydrol. Earth Syst. Sc. Discussions 9, 8425-8453, doi:10.519/hessd-9-8425-2012.

Xu, X., Werner, M., Butzin, M., Lohmann, G., 2012. Water isotope variations in the global ocean model MPI-OM. Geosci. Model Dev. 5, 809-818.

Yoshimura, K., Kanamitsu, M., Dettinger, M., 2010. Reginal downscaling for stable water isotopes: a case study of an atmospheric river event. J. Geophys. Res. 115, D18114. http://dx.doi.org/10.1029/2010JD014032.

Zimmermann, U., Ehhalt, D., Munnich, K., 1967. Soil water movement and evapotranspiration change in the isotopic composition of water. In: Isotopes in Hydrology. International Atomic Energy Agency, Vienna, Austria, pp. 567585 . 